\title{
LA PROSE AMOUREUSE ARABO-ISLAMIQUE : DE L'ISNĀD TRADITIONNEL AUX SOURCES LIVRESQUES
}

\author{
Monica Balda-Tillier \\ INSTITUT FRANÇAIS DU PROCHE-ORIENT (IFPO)
}

This article focuses on the method of transmission in ahbār belonging to the Arabic literary genre of love prose. The survey of the system of quotations in thirteen love treatises written between the 4th/10th and the 11 th/17th centuries indicates that the traditional $i s n a \bar{a}$, in which the names of the transmitters are included, was progressively abandoned. Authors starting from Mugultāy (d. 762/1361) chose instead to favour quotations of books by their titles, even though the preferred method of transmitting knowledge was still oral during the Mamluk period. Use of written 'references' not only indicates a formal change of conventional practice, but also implies the willingness of later authors to claim a kind of authorship in reshaping stories taken from old material.

L'histoire de la littérature arabo-islamique compte une quinzaine de traités d'amour conservés, dont la production s'est étendue sur huit siècles environ. $\mathrm{Du}$ point de vue chronologique, les premières monographies sur l'amour ${ }^{c} u d r i t e$, contenant une discussion théorique sur l'amour-passion $\left({ }^{c} i \check{s} q\right)^{1}$ et pouvant être considérées comme de véritables traités d'amour, sont la Risāla fí $l^{c}{ }^{c} i \check{i s} q$ wa-l-nisă $\bar{a}^{\supset}$ et la Risālat al-qiyān d'al-Ğāhiz (m. 255/869). Le plus tardif des ouvrages de ce type

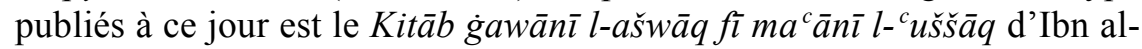
Bakkāo al-Balhī (m. 1040/1630). Tous les ouvrages qui traitent exclusivement de l'amour 'courtois' et qui furent écrits entre ces deux extrêmes, partagent, malgré leurs différences, un certain nombre de thèmes communs, comme l'essence de l'amour-passion (māhiyyat al$\left.{ }^{c} i \check{s} q\right)$ et les états $(a h w w \bar{a} l)$ des amants, ${ }^{2}$ ce qui permet d'évoquer un véritable 'genre littéraire'. Dans tous ces traités d'amour, une discussion théorique sur l'attitude à adopter face à l'amour-passion est accompagnée et étayée par des notices relatant l'histoire d'amants éprouvés par le ${ }^{c} i \check{s} q$, chaque auteur introduisant un nombre limité d'histoires originales. ${ }^{3}$ Cet

1 A. Cheikh-Moussa, 'La négation d'éros', 73.

2 L. A. Giffen, Theory of Profane Love, xiii et xv.

3 Stefan Leder observe, à propos de la transmission du habar littéraire, que 'authors of compilations are [...] not supposed to have produced the texts they present. In most of our sources we find quotations mostly without any indication 
article analyse les déclarations des auteurs concernant les sources qu'ils utilisèrent, ainsi que les passages où ils exposent au lecteur la méthode adoptée dans la rédaction de leurs notices. Cette étude de cas se fonde sur un corpus limité aux traités d'amour, dont l'histoire peut être considérée comme représentative de tendances plus générales dans l'évolution de la littérature de langue arabe.

L'authentification du habar par la mention de son origine fut très tôt introduite dans l'adab, ${ }^{4}$ bien que les auteurs fassent souvent une utilisation 'allégée' de cet instrument. ${ }^{5}$ L'isnād de l'adab n'a d'ailleurs pas la même fonction que dans le hadīt, car il ne sert pas véritablement à établir l'origine d'un texte. ${ }^{6}$ La méthode de l'isnād est traditionnellement liée à l'oralité. Il témoigne de la riwāya, ou transmission orale d'un texte écrit. Bien qu'elle fasse souvent référence à l'écrit, la riwāya est donc strictement liée au concept de tradition orale. ${ }^{7}$ Le prestige de cette forme de transmission du savoir, née entre la fin $\mathrm{du} \mathrm{II}^{\mathrm{e}} / \mathrm{VIII} \mathrm{e}^{\mathrm{e}}$ siècle et le début $\mathrm{du} \mathrm{HI}^{\mathrm{e}} / \mathrm{IX}^{\mathrm{e}}$ siècle, lorsque les premières collections de hadīt $\underline{\mathrm{s}}$ (mușannafs

of the written sources used - from scholars who were themselves occupied with the collection and transmission of $a k h b \bar{a} r$ ' (S. Leder, 'The Literary Use of the Khabar', 380). Malgré cela: 'Comparison of parallel narratives have demonstrated the proportion of divergences and shown that the editing of akhbār implies operations similar to authorship.' (ibid., 384).

4 Jacqueline Sublet remarque qu' avec les traditions, on enseigne 'les sciences religieuses' ('ilm et $m a^{c}$ rifa) qui sont à considérer en relation constante avec la science que l'on peut dire profane ( $a d a b)$. Dans l'adab qui concerne l'ensemble des connaissances reçues notamment des ancêtres que l'on prend pour modèles, on trouve toute une culture profane qui inclut la poésie, l'art oratoire, la rhétorique, la grammaire, mais aussi les traditions historiques et tribales des anciens arabes. Ces trois aspects de la science, ${ }^{\mathrm{c}}$ ilm, ma ${ }^{c}$ rifa et adab restent étroitement liés et sont véhiculés ensemble, horizontalement chez les contemporains et dans l'étendue de l'aire de l'Islam; verticalement dans le temps de génération en génération; ils sont transmis par voie orale et écrite selon des modalités bien définies.' (J. Sublet, 'Le modèle arabe', 14).

5 Une exception, dans un genre littéraire différent, est représentée par Ibn ${ }^{\mathrm{c}} \mathrm{Abd}$ Rabbih (m. 328/940) qui déclare dans l'introduction du ${ }^{c} I q d$ al-farīd 'that akhbār stand alone on their own merits, without the authentication of long isnāds which would destroy their brilliance' (J. Bray, 'c Abbasid Myth and the Human Act', 15). J. Bray remarque également qu' Ibn ' $\mathrm{Abd}$ Rabbih puts his trust in the wisdom of books and the individual exercise of reason by the reader, instead of in the methods of orally based teaching which subject the individual to the consensus of the study circle and the authority of a master' (ibid., 17).

6 H. Kilpatrick, Making the Great Book of Songs, 95.

7 S. Leder, 'Spoken Word and Written Word Text', 1. 
et musnads) furent couchées par écrit, ${ }^{8}$ s'est perpétuée dans la culture arabo-islamique jusqu'à une époque très tardive $e^{9}$. À partir de la deuxième moitié du $\mathrm{II}^{\mathrm{e}} / \mathrm{VIII}^{\mathrm{e}}$ siècle, la transmission du habar devint une discipline à part, bien qu'elle continuât à utiliser la méthode de l'isnād. ${ }^{10}$ Jonathan Berkey remarque que le prestige de cette méthode de transmission demeura intact pendant longtemps et que la valeur de la connaissance acquise par les livres continua à faire l'objet de doutes à l'époque mamelouke. Selon lui, la véritable connaissance venait, encore à cette époque, uniquement d'une personne instruite. ${ }^{11}$

Cet article propose d'analyser les passages qui font référence à la transmission des notices dans un corpus de treize traités d'amour, couvrant une période d'environ sept siècles. La première partie de ce travail relève et compare les données textuelles concernant la transmission des notices sur les amants dans les ouvrages qui précèdent chronologiquement al-Wädih al-mubīn fì dikr man ustušhida min almuhibbin de Mugulțāy (m. 762/1361). La seconde partie est entièrement consacrée au Wădih̆, qui représente un tournant dans l'histoire de la citation de références livresques explicites. Enfin, la troisième partie se penche sur l'évolution des méthodes de citation chez les auteurs postérieurs à Mugulțāy.

A. Les sources des notices sur les amants avant Mugulțāy (m. 762/1361) Comme tout ouvrage d'adab, les traités d'amour mêlent poésie et prose, auxquelles s'ajoutent des citations du Coran et du hadīt. Chacune de ces composantes (à l'exception des citations coraniques) est traditionnellement précédée d'un isna $\bar{d}^{12}$ dans lequel figurent les noms

8 J.A.C. Brown, Hadith. Muhammad's Legacy, 31.

9 Gregor Schoeler remarque à ce propos: 'The claim of 'heard/audited transmission' (al-riwāya al-masm $\bar{u}^{c} a$ ) was in principle still in force even in the age of madrasa, irrespective of the fact that, in most cases, transmission took place on the basis of books. 'Heard transmission' continued to play a practical role and beginning from the fourth/tenth and the fifth/eleventh centuries, assumed new forms : a book heard from or read to an author was tagged with a written 'endorsement', the iğäzat al-sam $\bar{a}^{c}$. Arab scholars always regarded and still regard manuscripts with such a $\operatorname{sam}^{c}$ 'endorsement' as superior to those without it.' (G. Schoeler, The Oral and the Written, 44).

10 S. Leder, 'The Literary Use of the Khabar', 313.

11 J. Berkey, The Transmission of Knowledge, 26. 
des transmetteurs du matn (contenu). L'ensemble de l'isnād et du matn constitue le habar ou 'unité d'information'. ${ }^{13}$

Dans les traités d'amour qui suivent, tous antérieurs au Wädih, la méthode suivie par chaque auteur pour renvoyer à ses sources a été relevée. ${ }^{14}$

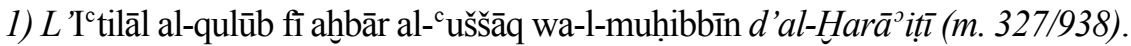

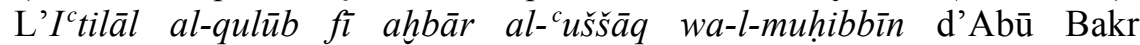
Muhammad b. Ğa ${ }^{c}$ far al-Sāmarrī al-Harāōițī, qui enseigna le hadīt à Damas $^{15}$, est le premier d'une série d'ouvrages sur l'amour à caractère moralisant et d'inspiration religieuse. Par la suite, les hanbalites Ibn alĞawzī (m. 597/1200) et Ibn Qayyim al-Ǧawziyya (m. 751/1350) reprendront dans leurs traités plusieurs idées et exemples apparaissant dans $1^{\prime} I^{c} t i l a \bar{l} .{ }^{16}$ Le livre est composé dans une perspective religieuse et éthique, son auteur essayant de combattre la tradition littéraire amoureuse profane sur la base du Coran, du hadīt et d'anecdotes pieuses. ${ }^{17}$ Beatrice Gruendler observe qu'il rapporte sans les commenter une grande variété d'opinions différentes à propos de l'amour. ${ }^{18}$

Dans cet ouvrage, al-Harā ${ }^{\top} i t ̦ \overline{1}$ emploie une méthode de transmission traditionnelle, quel que soit le domaine auquel appartient l'information qu'il donne. Il mentionne un grand nombre de hadịts munis de chaînes de garants qui témoignent, du moins formellement, d'une transmission orale. Pas une seule source écrite n'est citée explicitement. Parmi les noms des transmetteurs qu'il mentionne dans ses isnāds, ceux de Wahb b. al-Munabbih, ${ }^{19}$ d'al-Haytam b. ${ }^{\mathrm{c}} \mathrm{Adi},{ }^{20}$ d'al-Zubayr b. Bakkār ${ }^{21}$ et

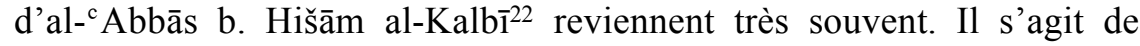

13 'The basic meaning of khabar denotes 'a piece of information' as reflected also by the verbal use of this root. In a literary context, however, the notion applies to narration in a more general sense.' (S. Leder, 'The Literary Use of the Khabar', 279).

14 Nous avons consacré plus ou moins de place à chaque auteur de traité d'amour en fonction de l'intérêt que sa méthode de citation des sources présente pour notre étude.

15 (Réd.), ${ }^{\mathrm{c}}$ al-Kharā̄ôț̄̄”, $E I^{2}$, iv, $1088 \mathrm{~b}$.

16 L.A. Giffen, Theory of Profane Love, 16.

17 Ibid.

18 B. Gruendler, 'Pardon Those Who Love passionately', 191.

19 Al-Hुarāòiți, I' ${ }^{c}$ ilāl al-qulūb, 50, 57, 65, 129, 165.

20 Ibid., 61, 95, 157, 211, 212, 231, 233, 234, 237, 259, 267.

21 Ibid., 79, 80, 81, 86, 88, 97, 100, 101, 151, 167, 178, 182, 207, 208, 210, 214, $223,253,254,255,261,270,283,286,300,320,305,322,326,346,349$ (2 fois).

22 Ibid., 114, 213, 242, 269, 272, 320. 
personnalités célèbres, connues comme transmetteurs d'ahbār. Ces auteurs seraient parmi les premiers à avoir couché par écrit des histoires d'amour de poètes bédouins, qui étaient auparavant connus pour leur valeur guerrière, et à les avoir ainsi transformés en héros de romans 'courtois'. ${ }^{23}$ Même si al-Harāo ițī a utilisé leurs livres ou leurs cahiers de notes, il ne le mentionne pas clairement. Dans son ouvrage, le prestige de l'isnād traditionnel, qui donne l''illusion' d'une transmission orale, demeure intact.

2) Al-Mașūn fì sirr al-hawā l-maknūn d'Abū Isḥāq Ibrāhīm b. ${ }^{c}$ Alī alHușrī al-Qayrawānī (m. ap. 413/1022)

Le Kitāb al-Mașūn fì sirr al-hawā l-maknūn d'al-Ḥușrī pose tout particulièrement la question de savoir quand l'on doit, ou quand l'on peut, garder ses sentiments secrets. L'œuvre constitue un lien essentiel dans la transmission de la matière littéraire sur l'amour entre les auteurs $\mathrm{du} \mathrm{III}^{\mathrm{e}}$ et ceux du IV ${ }^{\mathrm{e}}$ siècle de l'hégire. ${ }^{24}$ Elle représente probablement l'anneau de conjonction entre l'histoire du ${ }^{c} i \check{s} q$ profane et le soufisme. ${ }^{25}$ Pour la première fois, amour profane et amour divin sont mélangés.

Dans le Maṣūn les chaînes de transmission traditionnelles sont dans la plus part des cas omises. Al-Ḥuṣrī introduit ses $a h b \bar{a} r$ à la première personne, ${ }^{26}$ par un seul nom (qāla fulān), ou par une vague indication qui ne donne aucune information sur l'identité de celui qui parle. ${ }^{27}$ Dans deux cas seulement, les titres d'ouvrages écrits remplacent ces mentions. ${ }^{28}$ La référence aux sources reste donc imprécise chez al-Ḥuṣrī, qui ne fait pas usage de l'isna $\bar{d}$ nominal traditionnel et n'applique guère non plus la méthode 'moderne' de citations 'livresques'.

3) Ṭawq al-ḥamāma fì l-ulfa wa-l-ullāf d'Ibn Hazm (m. 456/1064)

Le Tawq al-hamāma du célèbre juriste andalous Ibn Hazm constitue un cas particulier dans l'histoire du genre littéraire des traités d'amour. Bien qu' Ibn Hazm reste fidèle à la tradition orientale, ${ }^{29}$ les critiques ne manquent pas de souligner l'originalité de son ouvrage et le tour

23 Voir à ce propos l'article de R. Blachère, 'Problème de la transfiguration du poète tribal'.

24 L.A. Giffen, Theory of Profane Love, 21.

25 R. Ben Slama, al- ${ }^{c} I \check{s} q$ wa-l-kitāba, 219.

26 Cf., 'Fa-wağadtu' (al-Husurīi, al-Mașūn, 15).

27 Cf., 'wa-qāla bac ḍ al-hukamāo', 'wa-qāla bac ḍ al-tarāğima' (ibid., 17).

28 Il s'agit du Kitāb Fiqh al-lugia et d'al-Kitāb al-mubhiğ d'al-Ta âlibī (ibid., 166 et 331).

29 G. Martinez, 'L’amour-trace !', 1. 
autobiographique, marqué par la sincérité, ${ }^{30}$ qu'il possède. Ibn Ḥazm a souvent été témoin des histoires qu'il raconte et il déclare ne pas s'intéresser aux récits des anciens Arabes ( $a l-a^{c} r a \bar{b} b$ al-muqaddamūn), comme d'autres l'ont fait, car les notices qui les concernent ont déjà été transmises par un grand nombre d'auteurs. Le traité d'Ibn Hazm se caractérise ainsi par un nombre très réduit d'isnāds; en lieu et place, l'auteur déclare avoir été le témoin des événements ou avoir entendu personnellement raconter l'histoire, mais sans nommer ses sources, par souci de discrétion. La mention de sources écrites y est presque absente : il ne cite que quatre titres et ne nomme qu'un seul auteur. ${ }^{31}$

4) Mașāiri ${ }^{\text {al- }}{ }^{\mathrm{c}}$ uššāq d'al-Sarrāğ (m. 500/1106)

Célèbre traditionniste hanbalite de Bagdad, al-Sarrāğ est également connu pour son œuvre poétique. Il se serait consacré en priorité à deux types de travaux littéraires: la versification de livres de fiqh ou à sujet religieux, et des ouvrages d'édification morale relevant de l'adab. Le Mașāric ${ }^{c}$ ressortit à cette seconde catégorie. ${ }^{32}$ Le titre du livre (Trépas des amants) donne le ton de l'ouvrage. Dans cette anthologie dont les notices évoquent toutes des amours tragiques, les histoires des amants ne sont apparemment pas classées selon un ordre précis, ${ }^{33}$ et les thèmes évoqués par les vers et les anecdotes sont conformes à ceux des autres traités d'amour.

À la différence de ses deux prédécesseurs, al-Ḥuṣrī et Ibn Ḥazm, et selon ses propres déclarations, al-Sarrāğ aurait recouru à la méthode traditionnelle de transmission du habar, à laquelle il accorde une grande importance. Ses chaînes de transmission, très précises, comportent fréquemment la date et/ou le lieu où la transmission orale s'est produite. ${ }^{34}$ L'auteur cite souvent le nom du maitre qui lui a transmis les

30 R. Arié, Études sur la civilisation de l'Espagne musulmane, 225.

31 Il s'agit du premier livre de la Torah (al-Sifr al-awwal min al-Tawra), du Ahbār al-'Arab, d'une Siyar Mulūk al-Sūdān et du Kitāb al-Lafž wa-l-iṣlāh d'Abū l-Husayn Aḥmad b. Yahyyā b. Isḥāq al-Rāwandī (Ibn Hazm, Tawq alhamāma, 88, 141, 155 et 267).

32 S. Leder, 'al-Sarrādj', $E I^{2}$, ix, 66-7.

33 J.-C. Vadet, L'esprit courtois, 380-1.

34 Voici quelques exemples d'indications précises sur la transmission: ahbaranā Abū Bakr Muhammad b. Ahmad al-Ardastān̄̄ bi-Makka fì Masğid al-

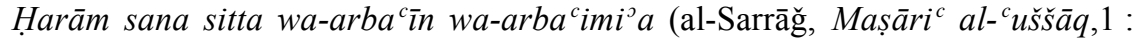
157) ; ahbaranā l-amīr Abū Muhammad al-Hasan b. ${ }^{c} \bar{I}_{s} \bar{a}$ b. al-Muqtadir bi-

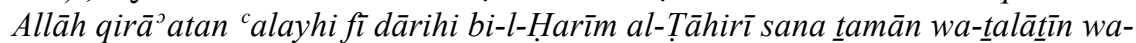

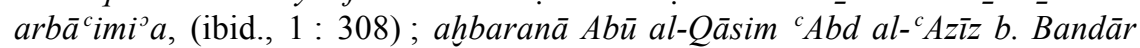


notices qu'il rapporte. ${ }^{35}$ À plusieurs reprises, l'auteur fait allusion à un texte écrit dont il aurait tiré certaines de ses notices, ${ }^{36}$ mais il n'en cite pas le titre. Seuls six titres d'ouvrages écrits sont cités explicitement. ${ }^{37}$

5) Rawḍat al-qulūb wa-nuzhat al-muhibb wa-l-maḥbūb d'al-Šayzarī (XI ${ }^{e}$ siècle) L'auteur de la Rawda est peu connu. Tout au plus peut-on établir qu'il fut juge à Tabariyya. La date de sa mort est inconnue, mais son moment de gloire peut être situé dans le dernier quart du XI $\mathrm{Xi}^{\mathrm{e}}$ siele. ${ }^{38}$ Parmi les traités d'amour qui nous sont parvenus, le Wädih est le premier, chronologiquement, à citer la Rawḍt al-qulüb. Les auteurs des traités

al-Šayzarī bi-qirā̄o tī calayhi fì maš̆id al-Harām bayna bāb Banī Šayba wa-bāb al-Nabì tuğāh al-Kac ba (ibid., 2 : 65).

35 La mention bi-qirä $\bar{a}^{3} a t \bar{c}$ alayhi, parfois suivie de la date et/ou du lieu où la transmission est advenue, apparaît dans les passages suivants : $1: 11,12,15,21$ (date), 21 (lieu), 26 (lieu), 31, 33, 36, 44, 49, 55, 67 (lieu), 85, 87, 91, 100, 102 (le lieu) ; 107, 113, 115, 120, 122, 124, 126, 127, 128, 131 (lieu), 138, 154 (date), 156 (date et le lieu), 161, 162 (lieu et date), 164, 167, 16 (lieu et date), 172, 174, 176, 181 (date), 184 (date et le lieu), 186 (date et le lieu), 187 (lieu), 193, 199 (date et le lieu), 207, 238, 245 (date et le lieu), 255, 267 (2 fois), 269 (date), 275, 292, 309, 312. 2 :7, 18 (date), 20 (lieu), 25 (lieu), 41, 50, 56 (date), $86,94,98,113,192,199,253,285,287$.

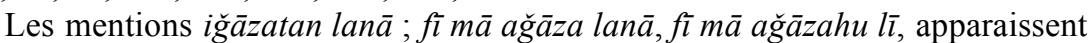
dans les passages suivants : 1 : 112, 147, 150, 153, $238 ; 2: 108,250,112,147$,

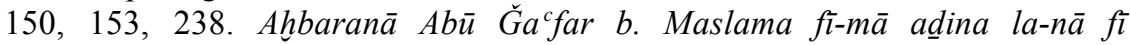
riwāyatihi : $1: 283$. Fi-mā adina lanā fì riwāyati-hi : $1: 42,306,313 ; 2: 61$.

36 Kataba ilayya: 1: 62, 227 ; ahbaranā Abū Ġālib Muhammad b. Ahmad b. Sahl b. Bišrān fì kitābihi ilaynā min Wāsit al- ${ }^{c}$ Irāq : $1: 82$; fì-mā kataba bihi ilaynā : $1: 63$; wağadtu bi-hatț : $1: 84 ; 2: 130$; naqaltuhu min hatțihi : $1: 250$, 288, 313, 314; 2 : 104, 107, 115, 275, 280 ; naqaltuhu min așlihi : 1: 39, 251 ; 2 : 26 ; wağadtu bi-hațt Abī ${ }^{c}$ Umar Muhammad b. al- ${ }^{c}$ Abbās b. Huyyawayh : 2 : 283 ; naqaltuhu minhu : $1: 280$; naqaltu min haț Ibn Huyyawayh : $1: 317$; min hatt Ibn Huyyawayh ${ }^{c}$ anhu : 1 : 323 ; wağadtu bi-hațt Abī ${ }^{c}$ Umar b. Huyyawayh wa-naqaltuhu min kitābihi : 1 : 92 ; haddața-nā Abü ${ }^{c}$ Abd Allāh Muhammad b. Abī Nașr al-Mu addin min lafẓihi wa-kitābihi : 1 : 94.

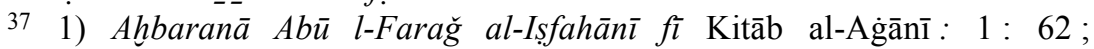
haddatanā Abū l-Farağ Muhammad b. ${ }^{c}$ Alì l-Iṣfahān̄ fì Kitāb al-Ag̀ān̄̄ : 1 : 227 ; 2) ahbaranā Abū Hafș ${ }^{c}$ Umar b. Muḥammad al-Makkī șāhib Qūt alqulūb: $1: 174$; 3) wa-bi-isnādihi qāla haddatanā l-Qā̄ì qāla; qara ${ }^{\circ}$ tu fì Nawādir Ibn al-A ${ }^{c}$ rābì : $1: 257$; 4) dakara lì annahu qara a a calayhi Dīwān alșabāba wa-qara tuhu calayhi ğam̄̄ ahu bi-Dimašq : 1 : 302 ; 5) ahbaranā [...]

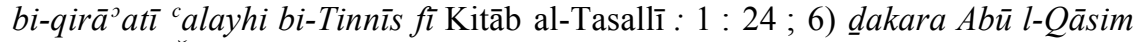
Manșūr b. Ğacfar al-Ṣ̂rafì fì kitābihi Kitāb al-Muğālasāt : 2 : 243.

38 D. Semah, 'Rawdat al-qulüb'. 
d'amour qui ont vécu après al-Šayzarī, que ce soit avant ou à la même époque que Muguulțāy (Šihāb al-Dīn Mạ̣mūd et Ibn Qayyim alĞawziyya), ne semblent pas connaître ce traité.

La Rawda n'inclut pas de véritables isnāds. Les ahbār sont souvent introduits par des expressions vagues dont les plus fréquentes sont hakā fulān (Untel raconta), ${ }^{39}$ hukiya (on raconta) ${ }^{40}$ et qīla (on dit). ${ }^{41}$ Seuls deux ouvrages écrits, dont al-Šayzarī affirme être l'auteur, y sont mentionnés comme sources. ${ }^{42}$

6) Dַamm al-hawā d'Ibn al-Ǧawzì (m. 597/1200)

Ibn al-Ğawzī est un des plus hauts représentants de l'école hanbalite et exerça une influence majeure sur le hanbalisme à l'époque ayyoubide. ${ }^{43}$ Son Damm al-hawa eut une influence capitale, dans la forme comme dans le fond, sur la Rawdat al-qulūb du hanbalite plus tardif Ibn Qayyim al-Ğawziyya (m. 751/1350). ${ }^{44}$ Le caractère moralisant de l'ouvrage, qui transparaît déjà dans son titre, est confirmé par le contenu. Ibn al-Ğawzī défend un enseignement traditionnel relatif à l'amour, en réaction à certaines pratiques soufies et aux théories d'Ibn Dāwūd et d'Ibn Hazm..$^{45}$ Le Damm al-hawā diffère des autres ouvrages du genre par sa discussion originale du désir et de la passion amoureuse. Les citations y ont une portée didactique, religieuse, morale et philosophico-éthique. Se présentant comme un médecin ou un éducateur, Ibn al-Ğawzī propose de guérir de la convoitise charnelle et de l'amour malheureux. ${ }^{46}$

Les isnāds d'Ibn al-Ǧawzī ne laissent apparaître qu'une seule mention explicite de livre comme source. ${ }^{47}$ Dans ses chaînes de transmission

39 Al-Šayzarī, Rawḍt al-qulūb, 11, 38, 41, 44, 49, 57, 59, 62, 64, 70, 71, 80, 105, 107, 109, 119, 122 (2 fois), 124, 138, 167, 163, 169, 179, 203, 215, 219, 248, 252, 259, 275, 285, 287, 295.

40 Ibid., 34, 69, 184, 189, 194, 200, 223, 251 (2 fois), 272, 276, 288, 289, 294.

41 Ibid., 60, 196, 197, 199 (2 fois), 200, 249, 250, 261, 277, 178, 280, 289, 290, 291 (2 fois), 296.

42 Wa-qad dakartu fì kitābī l-ma rū̃f bi-l-Tuhfa wa-l-țrfa ; wa-fì kitābì l-macrūf bi-l-Hadāo iq wa-l-țimār fì nawādir al-qudāat wa-l-buhalăa : ibid., 234 et 297.

43 H. Laoust, 'Ibn al-Djawzì', $E I^{2}$, iii, 774-5.

44 J. N. Bell, Love Theory, 9.

45 Ibid., 19.

46 S. Leder, Ibn al-Ğauzī, 70.

47 Wa-qad dakara Abū Bakr b. Dāwūd fì Kitāb al-Zahra (Ibn al-Ğawzī, Damm al-hawā, 319). Dans un autre passage, Ibn al-Ğawzī mentionne le Kitāb Ğamīl Butayna wa- ${ }^{c} A f r \bar{a}^{\supset} w a-{ }^{c} U r w a$ wa-Kutayyir. Beaucoup de ces 'ouvrages' portant le mot kitāa suivi du nom de deux amants sont mentionnés dans le Fihrist d'Ibn al-Nadīm (Fihrist, 478). Il ne s'agit probablement pas de véritables 
'traditionnelles', les noms des mêmes 'logographes' et qușṣạs cités par

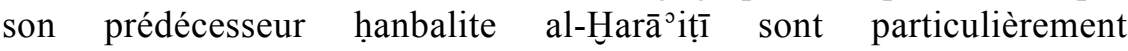
récurrents. ${ }^{48}$

7) Manāzil al-aḥbāb wa-manāzih al-albāb de Šihāb al-Dīn Mahmūd (m. 725/1325)

L'auteur du Manāzil al-aḥbāb wa-manāzih al-albāb est un cadi hanbalite. Son livre aurait influencé ses successeurs - en particulier Mugultạay, qui connaissait cet ouvrage, ${ }^{49}$ et Ibn Qayyim al-Ğawziyya.

Comme dans le Mașūn d'al-Ḥușrī et à différence du Mașāri ${ }^{c}$ al'ušš $\bar{a} q$ d'Ibn al-Sarrāğ et du Damm al-hawa d'Ibn al-Ğawzī, ses notices sont en général introduites soit par la mention d'un seul nom, ${ }^{50}$ soit par de vagues indications qui ne renseignent nullement ses lecteurs sur la source du habar..$^{51}$

Le Manāzil contient les titres de huit ouvrages écrits, pour un total de quatorze références explicites à des livres. ${ }^{52}$ Dans cinq de ces citations apparaît la mention bi-isnād dakarahu. Ce renvoi du lecteur à un isnād apparaissant dans un autre ouvrage semble représenter la première déclaration explicite de l'utilisation d'un livre comme source.

livres, mais de cahiers de brouillon servant d'aide-mémoire à l'usage des conteurs. M. Balda, 'Genèse et essor d'un genre littéraire', 124.

48 Wahb b. al-Munabbih (Ibn al-Ǧawzī, Damm al-hawā, 24, 43 ; 132, 215, 449) ; al-Haytam b. ${ }^{c}$ Adī (ibid., 49, 450) ; al-Zubayr b. Bakkār (ibid., 33, 136, 189, 191, 203, 217, 219, 248, 259, 264, 274, 290, 315, 373, 482, 483, 487, 491).

49 Par, exemple, le Wādih (255-259, 259-260 et 337-338) cite directement comme source le Manāzil al-aḥbāb dans trois notices, dont deux se suivent.

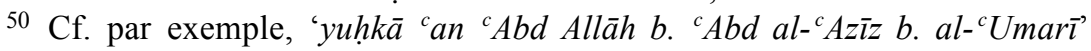
(Šihāb al-Dīn Maḥmūd, Manāzil al-aḥbāb, 89).

51 Cf. par exemple, 'su'ila bac ḍ al- 'ulamā' c an ahl al-hawā fa-qāla' (ibid., 63).

52 Dakara Ibn al-A A $^{c} \bar{a} b \bar{\imath}$ l-mac $r u \bar{f}$ bi-l-Wašš $\bar{a}^{\supset}$ fì kitābihi bi-isnād dakarahu (ibid., 11) ; wa-min asmā̄ihi wa-wașafātihi allat̄̄ dakarahā al-Hușrī fì kitābihi (ibid., 50) ; qad d̦akara al-Marzubān̄̄ fì Kitāb al-Riyāḍ (ibid., 67) ; wa-huwa mușannaf fì Kitāb al-Zahra $f_{\imath}$ al-mağāmi al-ši criyya (ibid., 86) ; wa-hakā Abū Bakr b. Dāwūd ${ }^{c}$ an Ta $a^{c} l a b$ bi-isnād dakarahu fì Kitāb al-Zahra (ibid., 205); dakara Abū Bakr b. Dāwūd fì habarihi (ibid., 223) ; wa-hakā al-Hasan al-Qāri ${ }^{{ }^{2}}$ fì Kitāb Mașāric al- ${ }^{\mathrm{c}}$ uššāq bi-isnād dakara-hu (ibid., 218) ; wa-fì Kitāb Ahbār al-A ${ }^{c}$ rāb bi-isnād dakarahu (ibid., 231); wa-d्dakara Abū Bakr Muhammad b.

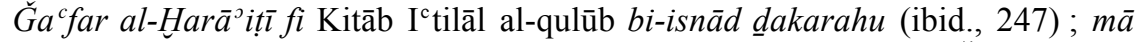

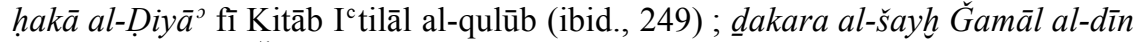
Abū Farağ b. al-Ǧawzī fì kitāb lahu yusammā 1-Miftāḥ (ibid., 279). 
B. Le cas d'al-Wāḍih mubīn fĩ dikr man ustušhida min al-muhibbīn de Muguultāy (m. 762/1361)

Dans les traités d'amour qui précèdent Mugiultāy, deux techniques

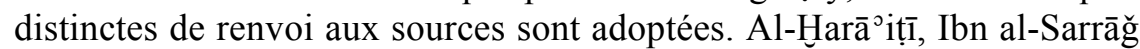
et Ibn al-Ğawzī utilisent en priorité des chaînes de transmission comportant plusieurs noms, qui ressemblent, au moins formellement, aux isnāds employés pour la transmission du hadīt. Cela tient en partie au caractère moralisant de leurs ouvrages, qui les rapproche du hadīt et de la sunna. Dans al-Mașūn, Tawq al-ḥamāma, Rawọdat al-qulūb et Manāzil $a l-a h b \bar{a} b$, les références aux sources restent en revanche imprécises et peu documentés, peut-être à cause du caractère supposé plus 'léger' de ces ouvrages et, dans le cas du Tawq et de la Rawdat al-qulūb, du rôle de témoin direct des événements narrés que joue l'auteur. Tous les ouvrages mentionnés ont néanmoins en commun le nombre très réduit de sources écrites mentionnées et le fait que l'auteur ne précise jamais comment il s'est servi des ouvrages dont il mentionne les titres.

Le Wāḍ̄h al-mubīn fi dikr man ustušhida min al-muhibbīn, ou Précis des martyrs de l'amour, fut écrit par Mugultāy, auteur d'origine turque qui vécut dans Le Caire des Mamelouks. Il mentionne quatre-vingt-deux ouvrages différents, ${ }^{53}$ dont plusieurs sont cités plus d'une fois, mais sans

53 Muguulțāy, al-Wāḍh al-mubīn: Kitāb al-Kāmil, Kitāb al-Dِahīra et Tadkirat al-ḥuffaz (19); Ta rīh Nīsābūr (19 et 42); Rustāq al-ittifāq fì mulah $\check{s} u^{c}$ ara $\bar{a}^{\supset}$ al-āfāq (21 et 91) ; Kitāb al-I tilāl (23, 24, 61, 238 et 342); al-Tafsìr (Kawāšī) et al-Tafsīr (Sufyān b. Sa ${ }^{c} \overline{1} d$ al-Tawrī, 2 fois) (23) ; Șaḥịh Muslim et Musnad Muḥammad b. Isḥāq al-Sarrāğ (24) ; al-Mubtadā ${ }^{\supset}$ et Tadbīr al-ă̌sām (29) ; Imtizāğ al-rūḥ ou Imtizāğ al-nufūs (30, 31, 43, 48, 62, 124, 137, 228, 229, 401 et 402); Rabī al-abrār (33); Maydān al- ${ }^{c} \bar{a} s ̌ i q \bar{i} n$ fì šarh aḥwāl al-wāmiqīn (34) ; Mihnat al-zirāf (37, 93, 278, 286, 307, 326 et 403) ; Kitāb al-Hikma (41, 103) ; al-Awșat et Kitāb al-Ṭabaqāt (42) ; al-Naqā̄id (44 et 125) ; al-Mantūur wa-l-manz̄ūr (44, 46, 61, 72 et 236) ; al-La ālī fì šarh al-Amālì ; Qadh al- ${ }^{c} \bar{a} \bar{l}$ fì al-Kalām al-La āà̄ ; Kitāb al-Fāṣil bayna al-hâfil ; Kitāb al-Kāmil et Kitāb alNišwār (44) ; Kitāb al-Mutayyamīn (49) ; al-Ğāmic (50); al-Mașūn (53,. 61, 69, 72, 350) ; al-Muhayī̄ (54); Bahğat al-maǧālis (62); Kitāb al-Azmina (66); Kitāb al-Alfāz et Kitāb al-Talhūṣ (70) ; Rawḍt al-qulūb wa-nuzhat al-mahabba wa-l-mahbūb (71, 144, 186, 216, 260, 337 et 367); Nawādir al-ușūl (88 et 236) ; al-Muštabah et Kitāb al-Ruwāt (90) ; Ta rīh Dimašq (91) ; al-Mufașșal li-l-Nāšsi (106) ; Kitāb al-Ṭawq (116) ; Damm al-hawā (116 et 395); Kitāb alZahra, Kitāb al-șahāaba; Usd al-gāa ba et Kitāb al-Ibāna (131); Amālī (Ibn Durayd) (154) ; Amālī (Muhammad b. Qāsim al-Anbārī) (155); Fiqh al-lug̀a (158) ; al-Ṭabaqāt (Ibn Qutayba) (163, 233 et 380) ; al-Mu č̆am (al-Marzubān̄̄) (179 et 261) ; al-Mustan̄̄r et Tark al-mirās fì l-ziyāda ${ }^{c}$ alā $M u^{c} \breve{g} a m$ al-šu ${ }^{c} a r \bar{a}^{\supset}$ (179); Kitāb al-Anīs (181 et 264); Amālī (Abū c Abd Allāh Muhammad b. 
qu'aucun ne se distingue véritablement des autres par le nombre de citations. Les livres mentionnés par Mugultāy relèvent de genres variés. Ils vont du traité de grammaire et de langue à l'anthologie littéraire, en passant par les recueils de hadīt et les ouvrages historiques, sans oublier les autres traités d'amour. Mugiulțāy privilégie clairement les citations 'livresques'. Certains passages renvoyant à des sources écrites témoignent également de la méthode utilisée par Mugulțāy dans la rédaction de son ouvrage et de l'utilisation littéraire qu'il en fait.

1) Le choix de la 'bonne' version

À travers l'histoire de Bišr et Hind ${ }^{54}$ qu'il affirme avoir tirée du Musnad de Šaraf al-Dīn al-Mișrī, Mugulțāy expose à ses lecteurs la méthode qu'il a adoptée dans le choix de la 'bonne' version de l'histoire. Le Wädih relate ainsi qu'une femme mariée, nommée Hind, tomba amoureuse de Bišr, un homme qui passait chaque jour devant chez elle lorsqu'il allait trouver le Prophète Muhammad. Elle lui envoya des vers où elle lui exposait ses sentiments, mais Bišr lui conseilla de prier Dieu afin de ne pas tomber dans l'adultère. Malgré cet avertissement, Hind insista tant qu'il décida de changer de chemin. Elle en tomba malade de chagrin, puis réussit à convaincre son mari de s'installer sur la route que Bišr empruntait désormais. Le voir à nouveau la guérit de sa langueur. Un jour, elle s'ouvrit à une vieille femme qui lui promit que son amour serait satisfait. Elle attira Bišr chez Hind par la ruse et les enferma ensemble. Le mari de Hind rentra plus tôt que prévu et, trouvant sa femme avec un autre homme, la répudia, puis alla demander au Prophète justice contre Bišr. Ce dernier convoqua Hind et la vieille femme, qui avouèrent leur méfait. Bišr tomba amoureux de Hind et demanda sa main, mais Hind

Ğa ${ }^{c}$ far al-Qanțarī) (187); ' Cqalā l-mağānīn (191 et 301); Kitāb al-Qiyān (205, 272 et 389); Kitāb al-Duhūl (207, 235, 241, 277, 325, 381 et 396); Ta roīh alQuds (220); al-Šāmil al-mufíd (223 et 383); Ahbār (al-Hāfiz Aḥmad b. Muḥammad b. ${ }^{\mathrm{C} A} \mathrm{lī}$ l-Anbūsī) (224); Kitāb Hišām b. al-Kalbī (226) ; al-Ta rīh̆ al-kabīr (Abū 1-Farağ al-Ișfahānī) (230 et 399); Kitāb al-Ṭabaqāt (Ibn Qutayba); Kitāb al-Lubāb (238); Rūh al-arwāh (260); Kitāb al-Muwallahīn (281); Ğāmic al-ladd Zakariyā al-Hağarī) (288 et 327); Kitāb al-Tasallì (297); Nawādir (al-Hağarī)

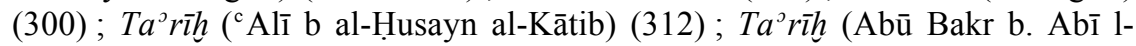
Azhar) (338); Amā̄l $\left(\mathrm{T} \mathrm{a}^{\mathrm{c}} \mathrm{lab}\right)$ (350); al-Mifțăh (366); Kitāb al-Amtāal (378) ;

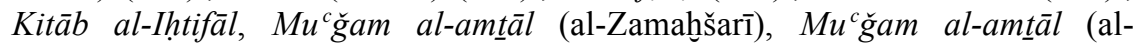
Maydānī) et $M u^{c}$ ğam al-amtāal (Ibn al-Sikkīt) (380); Kitāb Ahbār al-a ${ }^{c} r a \bar{b}$ (384) ; Kitāb al-Zubayrī (393); Kitāa al-Duca ${ }^{c} a f \bar{a}^{\jmath}$ (402).

54 Ibid., 125-31. 
refusa pour se venger de l'humiliation subie. Bišr en mourut de douleur. Informée de sa mort, Hind trépassa à son tour. À la fin du habar, l'auteur du Wädihh écrit :

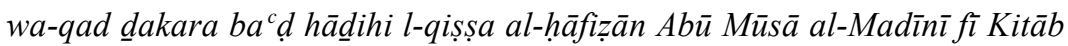

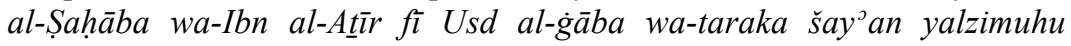
dikruhu stad̄karnāhu min Kitāb al-Ibāna. ${ }^{55}$

La version du Usd al-g்āba d'Ibn al-Ațīi ${ }^{56}$ ne comporte qu'une brève allusion à une histoire plus longue, avec un renvoi à un autre ouvrage pour la version complète. La mort des deux amants à cause de leur passion est omise. Or le $W a \bar{a} d i h$ se fonde sur le célèbre hadìt prophétique : man "ašiqa fa- ${ }^{c} a f f a$ fa-māta māta šahìdan (celui qui aime passionnément, reste chaste et meurt à cause de cet amour, meurt en martyr). ${ }^{57}$ Toutes les notices sur les amants que Mugulțāy rapporte se terminent avec la mort des amants en martyrs. La version du Usd ne convenait pas au projet littéraire de Mugulțāy et l'auteur du Wādih dut chercher dans une autre source une version adéquate de l'histoire. Notre auteur évoque cette recherche en citant les livres qu'il a consultés, au lieu de mentionner les versions différentes de la notice accompagnées d'isnāds traditionnels. De cette manière, il avoue également avoir croisé

55 'Abū Mūsā al-Madīn̄i dans Kitāb al-Ṣahāảba et Ibn al-Ațīr dans Usd al$\dot{g} \bar{a} b a$ ont mentionné des passages de cette histoire, mais ils en ont négligé d'autres qu'il était nécessaire de rapporter et que nous avons donc tirés du Kitāb al-Ibāna'. (La citation de ce livre est trop vague pour pouvoir identifier ce dernier ouvrage.) Ibid., 131.

56 Voici l'histoire dans Usd al-ḡāba: annahu kāna fì bid’ al-islām rağul šābb yuqālu lahu Bišr kāna yahtalifu ilā rasūl Allāh șallā llāh 'alayhi wasallama wa-kāna min ban̄ Asad b. ${ }^{c}$ Abd al- ${ }^{c}$ Uzza wa-kāna tarīquhu id̄à gadiya

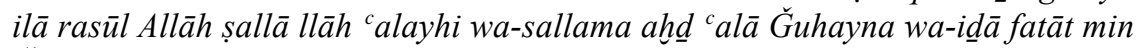
Ğuhayna nazarat ilayhi fa-tacaššaqathu wa-kāna bihā min al-husn wa-l-ğamāl hațt ${ }^{c}$ ażīm wa-kāna li-l-fatāt zawğ yuqālu lahu $S a^{c} d$ b. Sacid wa-kānat al-fatāt taq ${ }^{c}$ ud kull ġadāt li-Bišr ${ }^{c}$ alā an yağtāzu bihā li-yanzura ilayhā fa-lammā

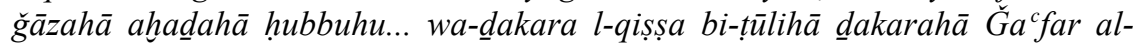
Mustagfarī. Au début de l'Islam, un jeune homme appelé Bišr allait fréquemment voir le Prophète - la Prière et le Salut de Dieu soient sur lui. Il appartenait à la tribu des Banū Asad b. ${ }^{c}$ Abd al- ${ }^{c} U z z a \overline{.}$. Pour se rendre chez le Prophète, il empruntait la route passant par Ğuhayna. Une jeune femme de cette tribu le vit et s'éprit de passion pour lui. Elle était très belle et avait un mari appelé $\mathrm{Sa}^{\mathrm{c}} \mathrm{d} \mathrm{b} . \mathrm{Sa}^{\mathrm{c}} \overline{1} \mathrm{~d}$. Elle s'asseyait tous les matins de manière à ce qu'il la voie en passant. Elle finit par tomber amoureuse de lui. Ğa ${ }^{c}$ far al-Mustaġarī a raconté l'histoire complète. (Ibn al-Atīir, Usd al-ḡāba, $5:$ :560-1).

57 Voir à ce propos M. Balda-Tillier, Un traité d'amour tardif, 129-54. 
plusieurs sources et remodelé le habar à sa guise. Or, selon la méthode traditionnelle, les auteurs n'admettent aucune participation dans l'élaboration d'un récit, ce qui donne l'impression que son contenu n'a aucunement été touché par leur créativité. ${ }^{58}$

Un autre exemple de la valeur accordée par Mugultāy aux sources livresques transparaît dans ce bref passage : lammā ğ $\bar{a} w a z a A b \bar{u} l{ }^{c} A b b \bar{a} s$ al-Taqafì bi-Makka wa-wağadtu bi-nusha: Abū l- ${ }^{c}$ Anbas. ${ }^{59}$ Le terme nusha renvoie à un texte écrit, et non à une riwāya.

\section{2) Les biographies}

Dans un autre cas, ${ }^{60}$ Mugulțāy apporte des précisions sur un personnage qu'il cite dans une de ses notices :

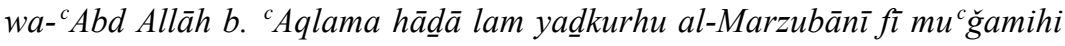
wa-lā fì kitābihi al-Mustanīr wa-lā Abū l-Fară̆ al-Umawì wa-dakartuhu fì kitābī l-musammā Tark al- mirās fĩ ziyāda ${ }^{\mathrm{c}}$ alā $\mathrm{Mu}^{\mathrm{c}}$ ğam al-šu ${ }^{\mathrm{c}}{ }^{\mathrm{ara}}{ }^{\mathrm{o}}{ }^{61}$

Ces références 'bibliographiques' précises semblent avoir pour fonction de permettre au lecteur de retrouver des informations sur le personnage cité.

\section{3) De nouvelles histoires}

Mugulțāy dit avoir tiré l'histoire de Nașr b. al-Hağğḡăğ du Kitāb alAmtāal de Ḥamza al-Ișfahān̄i. ${ }^{63}$ Les autres sources de cette notice qu'il indique par la suite sont Kitāb al-Ihtitifāl d'Abū 'Ubayd al-Bakrī, Kitāb al-Ṭabaqāt d'Ibn Qutayba, $M u^{c}$ ğam al-amtāal d'al-Zamahšarī, $M u^{c}$ ğam al-amtāal d'al-Maydānī, Kitāb Nuzhat al-anfus fì l-amtāal d'Ibn $\mathrm{Sa}^{\mathrm{c}} \mathrm{d}$ et un ouvrage sans titre par al-Marzubānī. Aucun isnād n'est mentionné, bien que parmi les personnages cités apparaisse le calife ${ }^{c}$ Umar et que la notice touche donc à la morale islamique et à l'histoire religieuse.

Les sources que Mugultạy cite pour cette notice ne sont pas des traités d'amour ${ }^{64}$ et la notice ne se trouve, à notre connaissance, dans aucun des

58 S. Leder, 'The Literary Use of the Khabar', 307-8.

59 Mugiultāy, al-Wädih al-mubīn, 226.

60 Ibid., 179.

61 'Ni al-Marzubān̄̄ dans son $M u^{c}$ ğam et dans son Kitāb al-Mustan̄̄r, ni Abū l-Farağ al-Umawī ne mentionnent ce ${ }^{c}$ Abd Allāh b. ${ }^{c}$ Aqlama, alors que je le mentionne dans mon livre Tark al-mirās fi l-ziyada ${ }^{c}$ alā $M u^{c}$ ğam al-šu $u^{c}$ ara $\bar{a}^{\jmath}$.

62 Mugultāāy, al-Wāḍih al-mubīn, 378-82.

63 Ibid., 378.

64 La seule exception est représentée par Ibn al-Marzubān, cité à la page 381, qui est bien l'auteur d'un traité d'amour. Malgré cela nous ne l'avons pas pris en compte, car Mugiulțāy ne rapporte pas sous l'autorité de ce transmetteur l'histoire dans sa totalité, mais uniquement le fait que la mutamanniya du 
traités conservés antérieurs au Wādị. Notre auteur déclare explicitement avoir comparé plusieurs versions écrites du habar pour choisir celle qui convenait le mieux à son propos et l'avoir ensuite introduite dans la tradition amoureuse dont elle ne faisait pas encore partie.

4) Variations sur le thème de l'amour

La mention de sources 'livresques' en lieu d'isnād offre à notre auteur la possibilité d'apporter des variations dans les histoires qu'il relate. Mugulțāy dit ainsi avoir tiré cette brève notice du Kitāb al-Zahra d'Ibn Dāwūd :

dakara Ibn Dāwūd fì Kitāb al-Zahra anna fatā yuqālu lahu Imru al-Qays hawā fatātan min hayyihi fa-lammā calimat bi-ḥubbihi lahä hağarathu fazāla caqluhu wa-ašfā calā l-talaf wa-șāra rahma li-l-nās fa-lammā balagiaha dēalika atat fa-ahadat bi- ${ }^{c} i d \bar{a}$ datay l-bāb wa-qālat: Kayfa ağiduka Imr'a l-Qays? Fa-qāla: 'atat wa-hiyạ̣̄̂u al-mawti baynī wabaynahä//wa-ğădat bi-wașlin hìna lā yanfac ${ }^{c}$ l-wașlu. ${ }^{65}$

Dans la tradition amoureuse, cette histoire apparaît dans les ouvrages suivants : Kitāa al-Zahra d'Ibn Dāwūd (m. 294/909); ;6 I' I $^{c} i l \bar{a} l$ al-qulūb d'al-Harāāițī (m. 327/939); ${ }^{67}$ Dַamm al-hawā d'Ibn al-Ğawzī (m. 597/1200); ${ }^{68}$ Manāzil al-aḥbāb de Šihāb al-dīn Mạ̣mūd (m.

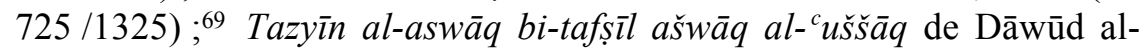
Anțākī (m. 1008/1599). ${ }^{70}$ Dans le Kitāb al-Zahra, l'histoire est la même, mot pour mot, que dans le Wädih ; comme dans l'ouvrage de Mugulțāy, elle ne comporte qu'un vers. Dans I'tilāl al-qulüb, dans Damm al-hawā,

proverbe cité à propos de ce récit ( $a s a b b$ min al-mutamanniya) serait la grandmère d'al-Hağğāăğ. Cf. Mugiulțāy, al-Wậ̣ị̣ al-mubīn, 381.

65 'Ibn Dāwūd mentionna dans le Kitāb al-Zahra qu'un jeune homme appelé Imru $^{\circ}$ al-Qays tomba éperdument amoureux d'une jeune femme de son clan. Quand elle sut qu'il l'aimait, elle se détourna de lui. Il en perdit la raison et dépérit, ce qui suscita la compassion des gens. Quand elle sut qu'il était au bord de la tombe, elle alla le trouver. Apparaissant dans le cadre de la porte, elle s'exclama : 'Comment vas-tu, Imru ${ }^{\circ}$ al-Qays ?'. Il répondit par ce vers :

Elle vint alors que l'abîme de la mort était déjà entre elle et moi ;

Elle m'accorda une visite lorsque la visite n'était plus d'aucune utilité.

Et il mourut.' (Muguulțāy, al-Wādịh al-mubīn, 121-2).

66 Ibn Dāwūd, Kitāb al-Zahra, 51.

67 Al-Harāàitị, I'tilāl al-qulūb, 187.

68 Ibn al-Ğawzī, Damm al-hawā, 383-4.

69 Šihāb al-Dīn Maḥmūd, Manāzil al-aḥbāb, 215-16.

70 Dāwūd al-Anțākī, Tazyīn al-aswāq, 208. 
dans Manāzil al-aḥbāb et dans Tazyīn al-aswāq, l'histoire est beaucoup plus longue et mentionne trois vers au lieu d'un seul.

Bien que la partie en prose soit presque identique, une comparaison entre le vers du Kitāb al-Zahra et celui du Wädihh montre que, même si les deux versions sont semblables au point du vue du sens, elles présentent des variantes significatives. Dans Kitāb al-Zahra, nous trouvons en effet :

danat wa-zalālu l-mawti bayn̄̄ wa-baynahāl/wa- ${ }^{\circ}$ adlat bi-wașlin hìna lā yanfac ${ }^{c}$ l-wașlu

Alors que le Wädih mentionne :

danat wa-hiyādu l-mawti baynī wa-baynahā//wa-ğādat bi-wașlin hìna lā yanfac ${ }^{c}$ l-waṣlu

Trois mots diffèrent dans la version du Wädihh par rapport à celle du Kitāb al-Zahra ${ }^{71}$ : atat à la place de danat, hiyāọ à la place de zilāl et $\check{g} \bar{a}$ dat à la place adlat. Le verbe atā a le sens de venir et danā celui de se rapprocher. Zilāl est le pluriel de zill, ombre. Le terme peut avoir la connotation positive d' 'absence d'ardeur du soleil' et indiquer le Paradis par opposition à la chaleur de l'Enfer, ou une connotation négative et signifier alors les ténèbres. Hiyä ${ }^{c} a r a b$, la fosse que l'on creuse pour y récolter de l'eau. Quant à adlat, il s'agit de la quatrième forme de dalā et le verbe a le sens de 'tendre, présenter quelque chose avec la main' (un cadeau, par exemple). Ğādat signifie 'être généreux'.

La version du Kitāb al-Zahra est beaucoup moins récurrente et n'apparaît que dans trois ouvrages, qui font tous partie de la tradition amoureuse (I'tilāl al-qulūb, Damm al-hawā et Tazȳ̄n al-aswāq). La version du Wādih est en revanche présente dans un nombre relativement important d'ouvrages qui n'appartiennent pas au même genre littéraire, notamment : $M u^{c}$ ğam al-udab $\bar{a}^{\mathcal{J}}$ de Yāqūt al-Hamawī (m. 626/1229) $;^{72}$

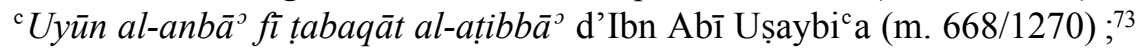

71 Nous sommes conscient que ces variantes pourraient être dues non pas à une intention explicite de l'auteur, mais à la fluidité textuelle qui accompagne la transmission des textes anciens. Dans le cas du Wädih, la version du habar donnée dans l'édition imprimée est néanmoins identique à celle d'un manuscrit copié du vivant de l'auteur. Ms Istanbul (Süleymaniye), Fātiḥ, 4143, f. 48v 1. 13-f. 49r 1. 2.

72 Yāqūt al-Hamawī, Mu č̆am al-udabāo $, 5: 467$.

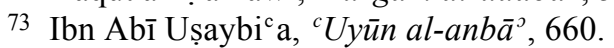


Al-Fahrī fì l-ādāb al-sulțāniyya d'Ibn al-Ṭiqțaqā (m. 709/1309); ${ }^{74}$ Nihāyat al-arab fì funūn al- ${ }^{c}$ Arab d'al-Nuwayrī (m. 733/1333) $;^{75}$ alWāfí bi-l-wāfayāt d'al-Ṣafadī (m. 764/1363) ; ;6 al-Kaškūl d'al- ${ }^{-1}$ Āmilī (m. 1030/1621). ${ }^{77}$

Dans un seul de ces ouvrages, al-Kašk $\bar{u} l$ d'al- ${ }^{c} \bar{A} m i l \overline{1}$ (qui est postérieur au traité de Mugulțāy), le vers est mentionné dans le même contexte que dans le $W a \bar{a} d i h$ et rattaché à la même histoire. Le $M u^{c} \breve{g} a m$

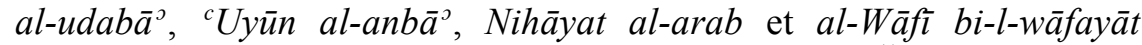
racontent tous qu'Abū Fạ̣l al-Kaḥhāl aurait offert à Šaraf al-Dīn Ibn ${ }^{c}$ Unayn un agneau qu'il trouva trop maigre. Al-Kaḥhāl lui aurait alors envoyé un long poème qui se terminait par le vers cité dans le Wädihh. Le vers est utilisé, dans ce cas, afin de railler un cadeau 'radin', ici un agneau trop maigre.

Dans une troisième anecdote, uniquement présente dans al-Fahrī d'Ibn al-Tiqtaqā, l'auteur relate l'histoire d'un vizir du calife al-Muqtafì (r. 530/1136-554/1160) qui le servit pendant longtemps, puis fut déchu et mourut de privations. Juste avant sa mort, le vizir aurait récité le vers en question (i.e. la version du Wädih) au calife qui était venu, enfin, lui rendre visite.

Un même vers, dont l'auteur n'est jamais mentionné, est donc utilisé dans trois contextes différents. Cependant, la version citée dans le Kitāb al-Zahra d'Ibn Dāwūd présente des variantes telles qu'on peut considérer qu'il s'agit d'un vers différent de celui présent dans le Wädih. Bien que Mugulțāy déclare au début de sa notice qu'il tire son habar du Kitāb al-Zahra, il n'a en réalité pris de son illustre prédécesseur que la partie en prose de la notice, la citation poétique étant empruntée ailleurs. Le choix de l'auteur du Wādih n'est pas anodin. En citant comme source de sa notice le Kitāb al-Zahra, Muguulțāy renvoie son lecteur à ce livre. En introduisant une variante, cependant, l'auteur 'signe' sa propre version d'une histoire déjà connue. Cela lui permet également d'appliquer la technique du ğidd et du hazl, qui consiste à intercaler parmi des $a h b \bar{a} r$ 'pédagogiques' et sérieux des propos plus légers, dans le but d'enseigner en amusant et d'éviter l'ennui - procédé littéraire que Mugultay affirme explicitement suivre dès son introduction.

${ }^{74}$ Ibn al-Ṭiqțaqā, al-Fahrī, 227-228.

75 Al-Nuwayrī, Nihāyat al-arab, 10 : 77-8.

76 Al-Ṣafadī, al-Wāfí bi-l-wāfayāt, $5: 147$.

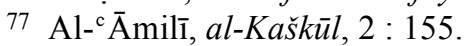


C. Les traités d'amour postérieurs au Wāạih

En légitimant la citation de sources écrites, en commentant son utilisation et en montrant l'usage littéraire qu'il était possible d'en faire, Muguultāy ouvrit la voie à ses successeurs, qui tirèrent profit de son exemple et mentionnèrent de plus en plus de livres. Une fois la référence à des sources écrites devenue acceptable, de nouveaux procédés furent mis en œuvre. Les auteurs les plus innovateurs dans ce domaine sont l'auteur anonyme du Kitāb $A s^{c} \bar{a} r$ al-aswāq fì ašc $\bar{a} r$ al-ašw $\bar{a} q$ et Dāwūd

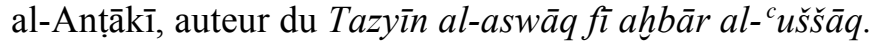

1) Rawḍat al-muhibbīn wa-nuzhat al-muštāqīn d'Ibn Qayyim alGawziyya (m. 751/1350)

Ibn Qayyim al-Ğawziyya est le plus célèbre disciple d'Ibn Taymiyya ( $\mathrm{m}$. 728/1328). ${ }^{78}$ La Rawda constitue la présentation la plus aboutie de la pensée hanbalite sur l'amour. ${ }^{79}$ L'auteur de la Rawda mentionne parmi ses sources trente-cinq ouvrages écrits, ${ }^{80}$ ce qui représente moins de la moitié de ceux cités par le Wādihh pour un nombre équivalent de pages. Ses sources ne sont pas aussi variées que dans le Wādih : bien qu'il cite quelques ouvrages historiques ou d'adab, la plupart des livres mentionnés dans la Rawda sont des recueils de hadīt ou des ouvrages touchant aux sciences religieuses et à la morale islamique. Les Șahịhayn

78 Pour une biographie détaillée de ce personnage, voir L. Holtzman, 'Ibn Qayyim al-Jawziyyah', 202-23.

79 J. N. Bell, Love Theory, 92.

80 Ibn Qayyim al-Ğawziyya, Rawdat al-muhibbīn: al-Sihăh (35, 46, 54 (2 fois) et 55) ; al-Mu' ğam al-awșat (al-Ṭabarānī) (86, 242, 244 (2 fois), 247 (2

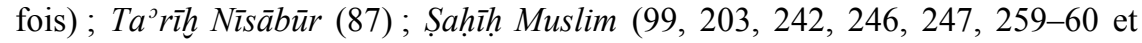
288); al-Sahihayn (204, 242 et 288); Șahīh Buhārī (243, 278 et 289); al-Șahīh ( 2 fois) $(289,290,311,312,342,347,363$ (2 fois), 393, 394, 396, 397, 404, 405, 407 (2 fois), 408 et 422); Musnad Muhammad b. Ishāq al-Sarrāă (99); Manāqib $a l$-Šăfic $c^{c}$ (116, 2 fois, 118 et 130) ; al-Kāmil (al-Mubarrad) et Kitāb rawāhu Mālik (117); Kitāb Rustāq al-Ittifāq (119); Šarh al-Kāmil (121); Ta rīh Bag̀dād (122); Kitāb Imtizāğ al-arwāh (145 et 367); Mihnat al-zirāf (147); Bahğat almağălis (173); Kitāb al-Zuhd (202); al-Musnad (Ahmad b. Hanbal) (243 (2 fois), 291, 308, 313, 346, 387 et 410); Sunan Ibn Māğah (245); Musnad Abī Yaclā l-Mawșilī (246); Ğāmic al-Tirmid̄ī (247, 387, 396 et 430); Ahbār al-

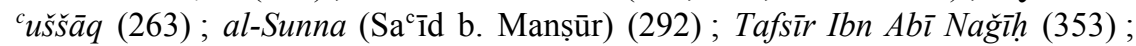
Tafsìr Abì Sălih (354); Tafsìr al- ${ }^{c}$ Awfä (355); Tafsìr Ibn Abì Dāwūd (356); alMusnad (Abū Muslim al-Layțī) (356); Tahrī̄m al-liwāt (359); Masā̉il Șāliḥ b. Ahmad (362); Rabī al-abrār (374); Sunan Abī Dāwūd (396 et 397); al-Sahịh wa-l-Sunan wa-l-Masānid (407); Musnad al-Hāriț b. Ab̄̄ Usāma (408); alMusnad (Ya ${ }^{\mathrm{c}} \mathrm{qū} \mathrm{b}$ b. Sufyān) (412) ; al-Musnad (al-Šāfí $\left.{ }^{\mathrm{c}} \overline{1}\right)$ (414). 
et le Musnad d'Ibn Hanbal sont fréquemment cités (respectivement 28 et 8 fois). Malgré le caractère 'moralisant' de l'ouvrage, qui le rapproche du Mașāric et du Damm al-hawā, et l'appartenance au courant hanbalite qu'Ibn Qayyim partage avec Ibn al-Sarrāğ et Ibn al-Ǧawzī, Ibn Qayyim se détache de ses prédécesseurs en omettant volontiers les isnāds. On retrouve à plusieurs reprises dans son ouvrage les expressions qīla ou yuqāl (on dit). ${ }^{81}$

2) Dīwān al-ṣabāba d'Ibn Abì Hağala (m. 776/1375)

Le Dīwān al-ṣabāba d'Ibn Abī Hağala fut probablement rédigé peu de temps après le Wädih et peut donc être considéré comme presque contemporain. Son auteur, après avoir étudié l'adab à Damas, devint le directeur d'un couvent soufi. Il aurait pourtant été plus intéressé par la littérature que par la pratique du soufisme. ${ }^{82}$ Le Diwān al-șabāba, son livre le plus célèbre, contient un grand nombre de citations du Coran et $\mathrm{du}$ hadìt, mais compte aussi des anecdotes parfois audacieuses et une grande abondance de vers, ce qui en fait, selon la définition de Beatrice Gruendler, un ouvrage d'adab pieux, semblable à l'I $I^{c} t i l a \bar{l}$ al-qulüb. ${ }^{83}$

Le Dīwān al-ṣabāba compte très peu de chaînes de transmission traditionnelles, qu'Ibn Abī Ḥağala n'utilise même pas pour citer le hadīt. Les titres d'ouvrages mentionnés sont en revanche relativement nombreux ( 30 pour 250 pages environ ${ }^{84}$ - une longueur qui correspond à un peu plus de la moitié du Wâạih). Les livres les plus cités sont des traités d'amour et des anthologies d'adab. Quelques ouvrages de langue sont également mentionnés.

81 Cf. par exemple, 'fa-ammā l-mahabba fa-qīla' (33) 'wa-qūla' (36, 37 etc.), 'yuqāl' (39).

82 J. Robson et U. Rizzitano, 'Ibn Abī Hadjala', $E I^{2}$, iii, 707-8.

83 B. Gruendler, 'ibn Abī Hağala', 121.

84 Ibn Abī Hağala, Dīwān al-șabāba: Manāzil al-aḥbāb (5 et 223); Kitāb

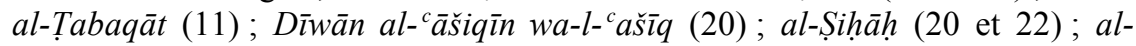
Saḥ̄ḥ (22 et 92) ; al-Sahl al-mawātī fì fậa $\bar{a}^{\supset}$ il Ibn Mamātī (30) ; Tuhfat al-ẓirāf (32); Imtizāğ al-arwāh (33 et 173) ; Rawdat al-muhibbīn (36, 89, 92 et 244) ; Naql al-kirām fì madh al-maqām (53); al-Wāạih al-mubīn (64 et 147); Fiqh alluġa (65) ; Ta rōhh al-Islām (74) ; Durrat al-g்awwāṣ (82 et 144); al-Matal alsāair (90 et 94); Mirāoat al- ${ }^{c} u q \bar{u} l$ (98); Tafsīr (al-Šayh Atīir al-Dīn Abū Hayyān) (98) ; al-Hamāsa (108); Sulūk al-sunan fì wașf al-sakan (113 et 115);

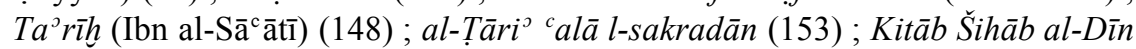

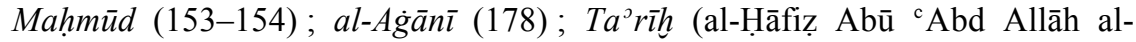
Buhārī) et Gंuniyat al-labīb ${ }^{c}$ inda gaybat al-țabīb (180); Kitāb al-Ad dkiya ${ }^{\circ}$

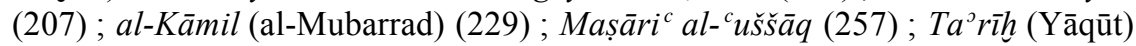
(262); Rawḍt al-qulūb wa-nuzhat al-muhibb wa-l-maḥbūb (266). 
3) Kitāb As ${ }^{c} \bar{a} r$ al-aswāq fì ašcār al-ašwāq (anonyme, $I X^{e} / X V^{e}$ siècle) Ce livre fut très probablement écrit à la même époque que le Tazyīn par un auteur originaire du Maghreb. Selon L. A. Giffen, il s'inspire largement du Aswāq al-ašwāq d'al-Biqāi $\bar{c}_{\overline{1}}$ (m. 885/1480). ${ }^{85}$ Dans le premier tiers de l'ouvrage, 49 titres de livres sont mentionnés. ${ }^{86}$ L'ouvrage le plus cité est Aswāq al-ašwāq (42 fois). ${ }^{87}$ Bien que l'isnād

\footnotetext{
85 L.A. Giffen, Theory of Profane Love, 45. Nous n'avons pas pu vérifier cette information.

${ }^{86}$ As $^{c} \bar{a}$ r al-aswāq : Rawḍtat al-qulūb wa-nuzhat al-muhibb wa-l-maḥbūb (f. 4v. 1. 21-2, 38r 1. 23 et 41r 1. 4-5) ; Dīwān al-șabāba (f. 5v 1. 6, 6r 1. 4 et 1.11 (2 fois), 6v. 1. 5, 7r 1. 5, 8v. 1.6 et 1. 8-9 (2 fois); 9v. 1.13 et 1.19 (2 fois), 10v. 1. 21-2, 13v. 1. 15, 22v 1. 9, 25r 1. 21, 43v 1. 11, 60v 1. 6-7, 62v, 1. 23, 65r 1. 13 et

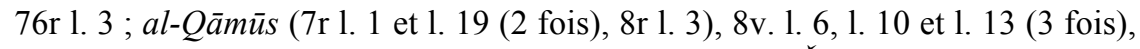
9v. 1. 13, 1. 16-17 et 1. 19, 10v. 1. 21-2 et 55v 1. 22); al-Ğami ${ }^{c}{ }^{1}$ i-1-Farrāo (f. $7 \mathrm{r} 1$.

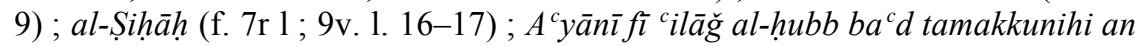
idrākahu (f. 7v 1. 21); Salwat al-muštāq (f. 7v 1. 21-2); Fiqh al-luġa wa-lșuwar al-garība (f. 12v. 1.13 et f. 15v. 1. 9) ; Rawḍat al-muhibbīn (f. 14v. 1. 13) ; Gunyat al-labīb cinda gaybat al-țabīb (f. 15r 1. 4-5); Rawḍat al-azhār (f. 15v, 1. 20-1, 19v 1. 21, 59r, 1. 22-3) ; Šarh al-Maqāmāt (f. 19v 1. 9, 30r 1. 8, 59r, 1. 18, 68v, 1. 15-16, 70r, 1. 11-12 et 71r, 1. 17) ; Sahịh (Muslim) (f 21r 1. 21-2 et 23r 1. 10-11) ; Șahīh (al-Buhārī) (f. 21v. 1.3 et 23r 1. 10-11) ; al-Adab al-mufrad (f. $21 \mathrm{v}$ 1. 4); Kitāb al-Amtā̄l (f. 21v 1.5 et 1.8 (2 fois); al-Awṣat (al-Ṭabarānī) (f. 21v 1. 11) ; Manāzil al-ahbāb (f. 22r 1. 4-5, 22v 1. 4-5, 41v 1. 23, 42r 1. 8, 69v 1. 5, 72r 1. 9-10) ; al-Mağālis (f. 22r 1. 11) ; Musnad li-1-Firdaws (f. 22r 1. 1314) ; Musnad Abī Ya ${ }^{c}$ lā al-Mawșilī (f. 22r 1. 13-14) ; Tatimmat dayl al-Amāl̄̄ (23r 1. 10-11) ; al-Ğāmi (Nașìr al-Kātib) (23v 1. 10-11); Kitāb al-Zahra (f. 24r 1. 22-3, 25r 1. 14 et 72v 1. 6) ; al-Manțūr wa-l-manz̄ūm (f. 24v 1. 17) ; al-Mașūn

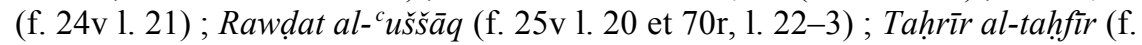
27r 1. 5) ; al-Risāla (f. 29v 1. 19-20); Harāo iq al-haqā̄iq (f. 31r, 1. 16); Mušāriq anwār al-qulūb (f. 32 1. 19) ; al-Hamāsa (f. 39r 1. 14); al-Waššāh (f.

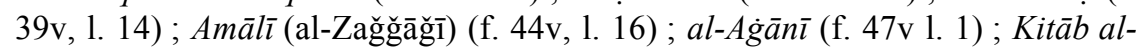
Ansāb li-l-Balādurū (f. 49r 1. 12-13) ; Kitāb Muġulțāy (f. 50r 1. 15) ; Murūğ aldahab (f. 52v 1. 11); Kitāb Imtizāğ al-nufūs (f. 53r 1. 20-1; 53v 1. 1-2); Hadīqat al-bādiya (f. 61r 1. 21-2) ; Kitāb al-Kāmil (f. 62v. 1. 11-12) ; al-Dahīra wa-Tadkira al-huffāz (f. 62v, 1. 12-13); Ta rīh Nīsābūr (f. 62v, 1. 14); alTabāqāt al-kubrā (Tāğ al-dīn al-Subkī) (f. 64r 1. 7-8); Kitāb Rustāq al-ittifāa fì milh šu $u^{c} a r \bar{a}^{j}$ al-afāq (f. 64v, 1. 4) ; al-Ișāba (f. 68v, 1. 9-11) et Mașāri al${ }^{c} u \bar{s}_{s} \bar{a} q$ (1. 12) ; Tahrī̄ (al-Dahabī) (f. 68v, 1. 13).

${ }_{87} A s^{c} \bar{a} r$ al-aswāq : f. 2 r. $1.19 ; 4$ r. $1.6 ; 15$ r $1.1 ; 16$ r 1. 15-16;16v. $1.23 ; 17 \mathrm{r}$ 1. $13 ; 20 \mathrm{r} 1.20 ; 21 \mathrm{r} 1.10-11+1.14 .+1.21-22$ (3 fois) ; 22r 1. 4-5;22v 1. 1; 26r 1. $11-12 ; 27 \mathrm{v} .1 .17-18 ; 30 \mathrm{v} 1.10+1.23$ (2 fois) ; 31r $1.5 ; 321.17 ; 32 \mathrm{v} 1.9+1$. 15-16 (2 fois) ; 33v 1. $13 ; 38 \mathrm{r} 1.23 ; 39 \mathrm{v}, 1.1 . ; 40 \mathrm{r} 1.10-11 ; 43 \mathrm{r} 1.2 ; 44 \mathrm{r} 1.7$; $44 \mathrm{v}, 1.4 ; 45 \mathrm{r} ., 1.4+1.14$ (2 fois) ; 49v 1. 8-9; 56r 1. $8 ; 56 \mathrm{v} 1.15 ; 57 \mathrm{r} 1.13 ; 59 \mathrm{v}$
} 
traditionnel n'y soit pas complètement abandonné, la 'citation livresque' est très présente dans le $K i t \bar{a} b A s^{c} \bar{a} r$ al-aswāq fí aš ${ }^{c} \bar{a} r$ al-ašw $w \bar{a} q$. L'auteur y cumule les références, notamment lorsqu'il s'agit d'apporter les définitions linguistiques et sémantiques des termes les plus communs du vocabulaire amoureux. Par exemple, dans un souci d'exhaustivité, l'auteur définit le mot ${ }^{c} i \check{s} q$ et ses dérivés, comme ${ }^{c} \bar{a} s ̌ i q$, en citant quatre ouvrages $^{88}$ qui traitent la question de points de vue différents : un traité d'amour, deux ouvrages de langue et un livre de hadīt. La mention de hadīt $\underline{s}$ s'accompagne également souvent de références à des ouvrages écrits. C'est notamment le cas du célèbre hadīt : 'Les esprits sont comme des soldats. Ceux qui se reconnaissent mutuellement s'allient et ceux qui s'ignorent s'opposent', ${ }^{89}$ qui apparait de manière récurrente dans les traités d'amour. L'auteur du Kitāb $A s^{c} \bar{a} r$ al-aswāq affirme tout d'abord l'avoir tiré du $A s w \bar{a} q$ al-ašwāq, qui l'aurait lui-même mentionné sous l'autorité du Șaḥịh de Muslim. Il mentionne ensuite qu'al-Buhārī commente ce dire prophétique dans son Șahịh ; le hadīt fut par la suite transmis dans le Kitāb al-Adab al-mufrad, dans le Kitāb al-Amthāl d'Abū al-Fath ainsi que dans al-Awṣat d'al-Ṭabarānī, dans la biographie de Muḥammad b. Faḍl. ${ }^{90}$ Cet exemple montre que l'auteur anonyme du Kitāb $A s^{c} \bar{a} r$ al-aswāq a accompli une recherche poussée afin de retrouver les ouvrages dans lesquels ce hadīt était mentionné ou commenté. Le résultat de cette recherche apparaît dans un 'isnād livresque' qui remplace en quelque sorte la chaîne de transmetteurs nominale traditionnelle.

Le Kitāb $A s^{c} \bar{a} r$ al-aswāq se distingue également par la précision de ses 'références bibliographiques'. Dans nombre de cas, l'auteur ne donne pas seulement le titre de l'ouvrage dont est tirée sa citation, mais mentionne également le chapitre ${ }^{91}$ (ou la maqāma, ${ }^{92}$ ou encore la biographie ${ }^{93}$ )

1. $12 ; 65 \mathrm{v} 1.11 ; 69 \mathrm{r}, 1.7-8 ; 70 \mathrm{r}, 1.12-13 ; 71 \mathrm{r}, 1.6 ; 71 \mathrm{v} 1.7 ; 73 \mathrm{r} 1.17 ; 74 \mathrm{v} 1$. $15 ; 78$ r 1. 13.

${ }^{88} A s^{c} \bar{a} r$ al-aswāq, f. 7r. Les ouvrages cités sont : al-Qāmūs, 1. 1, Dīwān alșabāba, 1. 5, al-Ğāmic d'al-Farrāo ${ }^{\circ}, 1.9$ et al-Sịhāh, 1. 9.

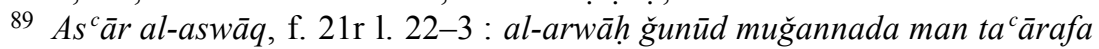
minhā ${ }^{\circ}$ talafa wa-man tanākara minhā htalafa.

$90 A s^{c} \bar{a}$ r al-aswāq, f. 21r 1. 22-21r 1. 11.

91 Cf. Kitāa As ${ }^{c} \bar{a} r$ al-aswāq : 'qāla fì Aswāq al- ${ }^{c}$ uššāq fì l-bāb al-ḩāmis', f. 26r, 1. 11-12 et 45r. 1. 14 ; ' 'dakara Abū ' Ubayd Muhammad al-Tamīmī fì Kitāb Imtizāğ al-nufūs [...].Wa-dukira ayḍan fì āhir al-bāb al-sābic', f. 53r 1. 20-1 -

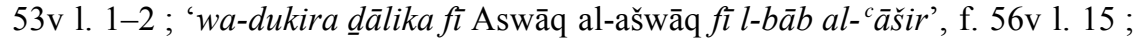
' hakā fì Hadīqat al-bādiya fì al-bāb al-țāmin', f. 61r 1. 21-2; 'hukiya fì al-bāb

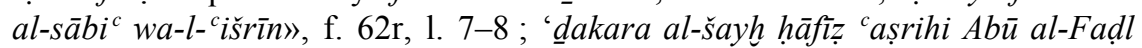


dans lequel se trouve le passage en question. Tout se passe comme s'il invitait le lecteur à se reporter lui-même aux pages évoquées.

Notre anonyme offre également au lecteur des indications sur sa méthode de collecte des notices. Lorsqu'il raconte l'histoire d'une jeune femme prête à commettre l'illicite, mais qui, grâce à l'exemple de l'être aimé, devint dévote et conduisit une vie d'ascète jusqu'à en mourir, l'auteur déclare avoir réuni le récit de Mugulțāy et la version donnée par al-Sarrāğ. ${ }^{4}$ Il signale ensuite à partir de quel endroit de l'histoire il s'appuie sur la version de Mugulțāy. ${ }^{95}$ L'auteur anonyme du Kitāb $A s^{c} \bar{a} r$ al-aswāq rend ainsi explicite par ses déclarations le travail de 'montage' qu'il a accompli et revendique la 'paternité' du habar tel qu'il le présente.

4) Tazyīn al-aswāq fī aḩbār al- ${ }^{c}$ uššāq de Dāwūd al-Anțākī (m. 1008/1599) Dāwūd al-Anțākī enseigna la philosophie et la médicine en Égypte et écrivit un grand nombre de livres, pour la plupart des traités de médecine. ${ }^{96}$ Le Tazyīn mentionne un grand nombre de sources écrites. L'on y compte 66 titres de livres sur un total de 550 pages (150 de plus que le Wādihh). La Nuzhat al- ${ }^{c} u s ̌ s \bar{a} q$ ou Nuzhat al-muštāq est citée 41 fois. ${ }^{97}$ Comme pour le Wāạih, les ouvrages mentionnés dans le Tazyīn appartiennent à des genres littéraires variés.

Qāẹ̄ l-quḍāt Šihāb al-Dīn Ahmad b. Hağar [...] fì l-qism al-awwal min kitābihi al-Ișāba fī qasm asmāo al-șahāba', f. 68v, 1. 9-11 ; ' dukira fì Aswāq al-ašwāq $f \grave{\imath}$ awwal al-bāb al-țān̄̄, f. 70r 1. 12-13, etc.

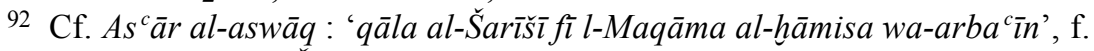
30r 1. 8; 'wa-qāla al-Šarī̌s̄ fì l-Maqāma al-sābica wa-l- 'išrīn', f. 59r, 1. 18; 'qāla al-Šarī̌š fì l-Maqāma al-țāniya wa-l-arbacìn', f. 68v 1. 15-16, f. 70r 1. 1112, 71r 1. 17, etc.

$93 \mathrm{Cf} . A s^{c} \bar{a} r$ al-aswāq, 'fa-rawāhu al-Ṭabarān̄̄ fì 1-Awșat fì tarğamat Muhammad b. al-Fadl', f. 21v1. 11, etc.

94 As ${ }^{c} \bar{a} r$ al-aswāq, f. 73v 1. 15-16.

95 'Wa-fì mā hakāhu Muğulțāy...', As 'cār al-aswāq, f. 74r 1. 1.

96 L'attribution du Tazȳ̄n à Dāwūd al-Anțākī a été remise en cause par Julia Bray ('Dāwūd ibn ' 'Umar al-Anțākī', 53-4), qui affirme que les données textuelles en notre possession de permettent pas de se prononcer définitivement sur la question.

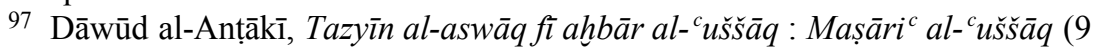
et 56) ; Dīwān al-ṣabāba (10, 31, 356, 408, 418, 442); Rustāq al-ittifāq fì milh šu ${ }^{c}$ ară $\bar{a}^{\supset}$ al-āfāq (15); Luzūm mā lā yalzam (18); Manāzil al-aḥbāb (19, 62, 78, 90, 93, 203, 208, 249, 417 et 527) ; Naqala Ibn Hallikān fī tarğamat al- ${ }^{\mathrm{c}}$ Allāf (24), Dayl al-Amālī (25); Sìrat al-Iskandar (29) ; Kitāb imtizāğ al-nufūs d'alTamīmī (29 et 372) ; al-Mantūur wa-l-manẓūm et al- ${ }^{c} \bar{A} l \bar{\imath}$ fi Šarh al-āmālì (30); al- 
Dans l'introduction du Tazyīn al-aswāq fì ahbār al- 'uššāq, al-Anțākī déclare que l'isnād traditionnel n'a pas sa place dans un ouvrage d'adab. ${ }^{98}$ Ses sources sont écrites : il déclare avoir tiré l'essentiel de ses notices du Mașāri ${ }^{c} a l^{c} u \check{s} \breve{s} \bar{a} q^{99}$ et du livre (qu'il ne nomme pas ${ }^{100}$ ) d'al$\operatorname{Biqa}^{\mathrm{c}} \overline{1}(\mathrm{~m} .885 / 1480){ }^{101}$ Il ajoute qu'il a abrégé l'ouvrage d'al-Biqa ${ }^{\mathrm{c}} \overline{\mathrm{i}}$, omettant notamment les isnāds qu'il ne considère nécessaires que pour le hadìt prophétique et pour étayer des règles religieuses (tawtīq al-ahkām al-dìniyya). ${ }^{102}$ À la place de la chaîne de transmission traditionnelle,

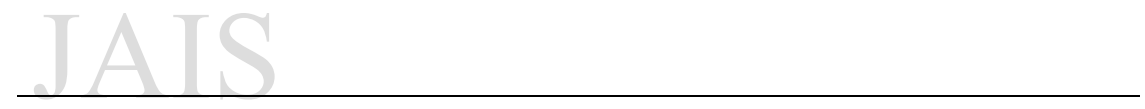

Hiliza (41 et 52) ; Amā̄l̄ (Ibn ' Asākir) (50, 58 (2 fois), 104); Kitāb al-Hăài ifin ou Kitāb al-Hawf (50 et 51); Šarh al-Šawāhid (58, 84, 183 et 321 (2 fois)); Šarh alDuraydiyya (60); Ta rīhihihi al-kabīr (Ibn ${ }^{\mathrm{c}}$ Asākir) (60) ; al-Aġāñ̄ (69, 99, 103, p. 172 et 262); Ğamharat al-nasab (74); Rawdat al-dawlatayn (76); Ta rīh (Šams al-Dīn b. Hallikān) (79) ; al-Nuzha (99, 104, 106, 111, 1142 fois, 117, 120, 132, $140,141,142,145,1512$ fois, $152,153,157,161,174,180,182,183,184,185$ (2 fois), 188, 190, 191, 194, 196, 206, 222, 225, 240, 280, 288, 307, 309, 312 et 316); Tasrīh al-Nāzir (104 et 114); al-Kitāb (114); Ta rīh (al-Dahabī) (134); Kitāb mağhūl al-tāo līf (134); Kitāb al-ansāb (140); Bulgat al-išfāq fì dikr ayyām

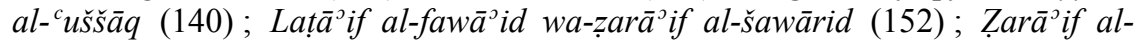
ahbār (153); Nadīm al-musāmara $(155,203,274$ et 282); Ahbāar al-Sūdān (158); Kitāb Ibn al-Ğawharī (159); Rawḍt al-qulūb (162, 181, 308, 356 et 373); Šarh al- ${ }^{c}$ Abdüniyya (163); Qūt al-qulūb fì ahbār al-muhibb wa-l-mahbūb (167 et 168 (2 fois)); Nihāyat al-arab (172); ; Uqalā l-mağānīn (174 et 221); Tasrīh al-nawāzàir (177) ; al-Tabaqāt (182) ; Muhtșar al-Tabaqāt (183); al-Rawd

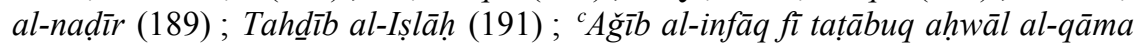

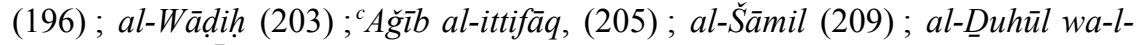

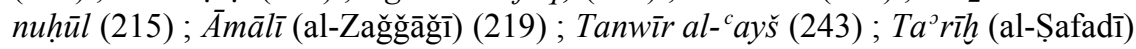
(252); Mahāsin al-buldān wa-nuzhat al-zamān (294); Tafsìr (Abū Ḥayyān) (295) ; al-Šahnāma (296); Durar al-afkār fì l-tahrī̄ọ calā tazwīğ al-abkār (297);

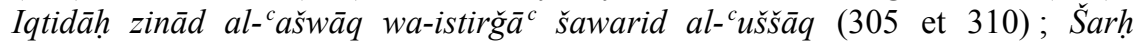

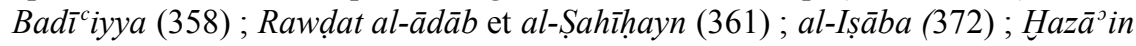

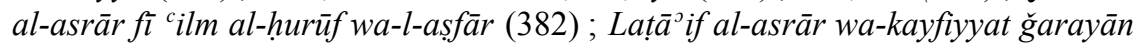
al-aqdār (383 et 389 (4 fois)); Tamarāt al-awrāq (417); Ihy $\bar{a}^{2}{ }^{c}$ ulūm al-dīn (432); Qisșat Ramla (535).

98 L.A. Giffen, Theory of Profane Love, 43.

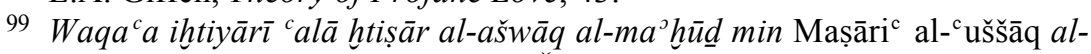
mansūb ilā Ab̄̄ Bakr Muhammad b. Ğacfar al-Bağdād Tazyīn al-aswāq, 9).

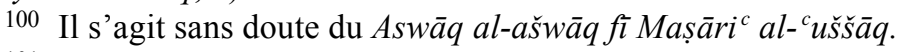

101 Dāwūd al-Anțākī, Tazyīn al-aswāq, 9.

102 Ibid., 10. 
Dāwūd al-Anțākī recourt à la citation livresque. Même un poème peut se voir introduit par une référence à un ouvrage. ${ }^{103}$

Souvent, l'auteur du Tazyīn ne se contente pas de citer une seule source. Dans certains passages, il en indique deux ou plus pour une même information ou pour une même histoire, comme pour renseigner le lecteur sur les multiples endroits où il peut la trouver. ${ }^{104}$ Il signale aussi la présence, chez d'autres auteurs, d'histoires semblables - bien que pas tout à fait identiques - à celle qu'il vient de raconter. ${ }^{105}$

Le cumul de références peut également avoir pour fonction d'apporter le plus de précisions possible sur l'identité d'un personnage ou sur une histoire. Dāwūd al-Anțākī mentionne qu'on amena un jour un jeune homme émacié à Ibn ${ }^{\mathrm{c}} \mathrm{Abbās}$. Le jeune homme lui récita des vers où il évoquait la souffrance que lui causait sa passion amoureuse. ${ }^{106}$ La notice n'est introduite par aucune référence bibliographique, mais après avoir raconté son histoire, al-Anțākī précise que, selon les Amālī d'Ibn ' ${ }^{\mathrm{C}}$ Asākir, le jeune homme était ${ }^{c}$ udrite. Il ajoute par la suite que, selon le Šarh alŠawāhid d'al-Suyūțī, il s'appelait ' Urwa b. Qays. Concluant l'histoire de ${ }^{\mathrm{c}}$ Urwa b. Hizām, l'auteur du Tazyīn affirme que, selon le $T a^{\circ} r \bar{r} h$ d'alDahabī, ' Urwa mourut sous le califat de 'Utimān en l'an 30 de l'hégire, alors qu'un autre ouvrage anonyme indique qu'il mourut au mois de $\check{s} a w w \bar{a} l$ de l'an $28 .{ }^{107}$

Un des ahbār qui composent l'histoire de Mağnūn ${ }^{108}$, tiré du Tasrīh al-nāz̧ir (dont l'auteur n'est pas mentionné), relate qu'on emmena Mağnūn se promener dans des campements, où on lui montra des

103 Cf. ibid., 15 où les vers sont précédés de cette mention 'wa-fi Rustāq alittifāq fĩ milh šu c $^{c} \bar{a}^{\supset}$ al-āfāq li-Ibn Mubārak al-imām'. À la p. 18 l'on trouve : 'wa-min Luzūm mā lā yalzam', suivit des vers, etc.

104 Cf. Dāwūd al-Anțākī, Tazȳ̄n al-aswāq, 30 : 'qāla al-Sukkarī wa-Ibn Abī

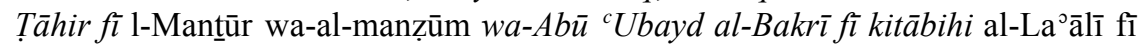
šarḥ al-Amālī', 50 : 'wa fì riwāyat al-Hāfiz Mug்ulțāy ${ }^{c}$ an Ab̄̄ l-Qāsim fì al-Amālī wa-Ibn Abī al-Dunyā fì Kitāb al-H̄ā̄ifìn', 60 : 'wa-qad sāqa al-qișșa Ibn Hišām fi Šarh al-Duraydiyya wa-d्dakarahā Ibn 'Asākir fi Ta ${ }^{\top}$ rīhihi al-kabīr', 60.

105 Cf. Dāwūd al-Anțākī, Tazȳ̄n al-aswāq, 203: 'wa-hādihi al-hikāya ahrağahā fì Nadīm al-musāmara wa-l-Šihāb fì Manāzil al-ạ̣bāb. Wa-l-Hāfìz Muğulțāy fì 1-Wāḍiḥ. [...] Wa-naz̄īruhu hakāhu al-Šayzarī 'an 'Utba'. La dernière phrase mentionnée n'est pas une référence explicite à un ouvrage écrit, mais nous pouvons formuler l'hypothèse que le nom de l'auteur dissimule en réalité une référence à son ouvrage, le traité d'amour intitulé Raw dat al-qulüb.

106 Dāwūd al-Anțākī, Tazyīn al-aswāq, 57-8.

107 Ibid., 134.

108 Ibid., 104. 
femmes plus belles les unes que les autres, afin qu'il oublie Laylā. Mağnūn échappa à ses compagnons qui le retrouvèrent en larmes, une gazelle dans les bras, en train d'épousseter son pelage. Al-Anțākī précise que tel est le récit du Tasrīh al-nāzirir, mais que la version de la Nuzhat al$m u s ̌ t a ̄ q$ ajoute qu'il aurait aussi récité un vers dans lequel il disait à la gazelle - qui ressemblait à Laylā - de ne rien craindre, car il était aujourd'hui son ami. ${ }^{109}$

Après avoir comparé différentes sources, al-Anțākī indique parfois laquelle est, selon lui, la plus 'juste' (sahīh). Au sujet de l'amour d'alȘimma pour son amie d'enfance Rayyā, il dénonce une version erronée affirmant qu'al-Șimma mourut parce qu'un devin lui prédit, lorsqu'il était en Iraq, que jamais il n'épouserait Rayyā. La 'véritable' histoire affirme al-Anțākī - est celle du Qūt al-qulūb, selon laquelle Rayyā fut fiancée à un autre homme de Mudhiğ qui l'emmena avec lui dans son pays. Quand al-Ṣimma fut informé de son départ, il en fut rempli de chagrin au point qu'il s'alita et mourut. ${ }^{110}$

Même pour les livres qui n'ont pas été écrits en arabe, Dāwūd alAnțākī n'accepte pas de références de 'seconde' main. Dans un passage du Tazyìn, il mentionne avoir lu l'histoire d'Abrawīz directement dans le Šahnāma, rédigé en persan, et l'avoir traduite. ${ }^{111}$

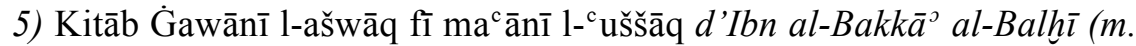
1040/1630)

L'auteur du Kitāb Ġawān̄̄ l-ašwāq est peu connu. Son traité d'amour se différencie des autres par une approche plus large du thème de l'amour. Il inclut en effet une partie sur l'amitié, ce qui n'est pas le cas pour les précédents ouvrages du même genre. ${ }^{112}$

L'isnād nominal traditionnel est omis. Les vers et les $a h b \bar{a} r$ sont souvent introduits par la mention d'un seul nom. ${ }^{113}$ On y compte également 26 ouvrages ${ }^{114}$ mentionnés explicitement sur un total de 150

109 'A yā šibha Laylā lā taḩăfina innan̄̄ // laki al-yawma min waȟsiyyatin lașadīqun', ibid. D'autres exemples du même procédé se trouvent à p. 114, 152, 183.

110 Dāwūd al-Anțākī, Tazȳ̄n al-aswāq, 167-8.

111 Ibid., 296.

112 G. J. van Gelder, [Review of] 'Ghawānī 1-ashwāq', 72.

113 Cf. par exemple 'haddata Abū Faḍl al-Šaybān̄̄', 23.

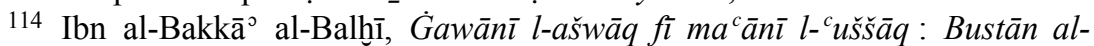
abrār wa-bahğat al-ahyār (11 et 45); al-Mu'ğam al-awșat (al-Ṭabarān̄i) (12 et 48) ; Šarh Lāmiyyat al- ${ }^{c}$ Ağam (13 et 22-23) ; al-Aj̇ān̄i (22) ; Wafayāt al-a ${ }^{c} y \bar{a} n$ (33 et 114) ; Bahğat al-nufūs (36) ; Kašf al-asrār (37-38 et 82); Dīwān al-șabāba (39, 66 et 96) ; Tafsīr (al-Bayḍ̄wī) (43) ; Mir āt al-zamān (47) ; al-Rayhāàn wa-l- 
pages environ (moins de la moitié du Wādih et du Tazyīn). L'auteur ne semble pas avoir privilégié une source en particulier aux dépens des autres. Il cite les traités d'amour de ses prédécesseurs et des anthologies littéraires.

\section{Conclusion}

Dans le genre littéraire des traités d'amour, deux tendances se profilent très tôt dans la manière de mentionner les sources. L'isnād traditionnel jouit de son prestige auprès des hanbalites al-Ḩarāôị̣̂, Ibn al-Sarrāğ et Ibn al-Ğawzī. Le Mașāric al- ${ }^{c} u \check{s ̌ s} \bar{a} q$ d'Ibn Sarrāğ, en particulier, se distingue par de longs isnāds, qui portent souvent la date et le lieu de la transmission orale. Dans d'autres traités antérieurs au $\mathrm{VIII}^{\mathrm{e}} / \mathrm{XIV}^{\mathrm{e}}$ siècle, comme le Tawq al-hamāma et la Rawdat al-qulūb, les notices sont généralement introduites par de vagues indications (un seul nom ou des verbes au passif: qīla, yuqāl et hukiya) qui ne fournissent aucun renseignement sur l'origine de la notice. La mention de sources livresques demeure rare.

À partir de Mugulțāy cette tendance est inversée. Le Wādih privilégie en effet la référence à de titres des livres, ce qui ouvre à l'auteur des perspectives plus vastes. Il mentionne en effet une source écrite pour plus de la moitié de ses notices (95 sur un total de 164). Bien qu'il coexiste avec le système d'isnāds nominal, le livre devient avec Mugulțāy non seulement une source avouée et avouable de transmission du savoir, mais acquiert également un prestige comparable à celui dont jouissait auparavant la chaîne de garants traditionnelle. Le contexte historique dans lequel il vécut, Le Caire de l'époque mamelouke, a probablement joué un rôle dans le choix de Mugulțāy de privilégier les sources 'livresques', si, comme observe J. Berkey: 'Written texts played an important role in education. Schools and mosques in Mamluk Cairo frequently housed large collections of books available for use'. ${ }^{115}$ Le sujet 'léger' de son ouvrage peut aussi avoir orienté son choix, l'auteur se sentant probablement moins lié par les obligations de 'l'oralité' que dans des ouvrages touchant aux disciplines religieuses. Sa démarche reste

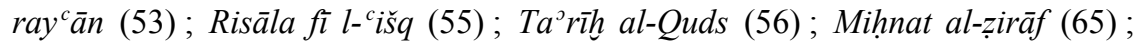
Imtizāğ al-arwāḥ (65); Rawḍat al-muhibbīn (76); Muruğ al-ḍahab (80); alHukm (91) ; Bisāt al-anwār (93) ; Tanbīh al-Ġäfilìn (96) ; al-Mustağād (121, 130,

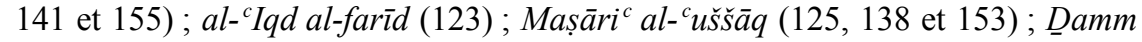
al-hawā (126); Manāzil al-aḥbāb wa-manāzih al-albāb (141); al-Farağ bac d alšidda, 156.

115 J. Berkey, The Transmission of Knowledge, 24. 
néanmoins originale et audacieuse, car la connaissance acquise par les livres demeurait, encore à cette époque, ambivalente. ${ }^{116}$

Bien que les auteurs précédant Mugulțāy aient très probablement déjà travaillé à partir d'écrits, l'isnād traditionnel ne constituant que formellement une référence à la transmission orale, c'est à partir du Wädih que la citation livresque commence à renvoyer le lecteur à la consultation d'un ouvrage antérieur, comme pour l'inviter à comparer les versions d'une même histoire. Cette méthode s'affine par la suite dans le Kitāb As $\bar{c} \bar{a} r$ al-aswāq, où la citation de livres se fait de plus en plus détaillée. La partie (voire le chapitre où la maqāma) du livre dont est tiré un passage y est précisée. L'auteur anonyme de ce traité, tout en restant en partie attaché à la méthode de transmission ancienne, remplace parfois les noms des transmetteurs par des titres d'ouvrages, aboutissant à la formation d' 'isnāds' d'un nouveau genre, que nous pouvons définir comme des 'isnāds livresques'. Enfin, chez Dāwūd al-Anțākī, la méthode traditionnelle de l'isnād est complètement abandonnée. Cet auteur omet systématiquement toute chaîne de transmission, qu'il remplace par des titres de livres. Dans son ouvrage, le prestige dont jouissait auparavant la chaîne de transmission nominale est définitivement transféré vers le livre.

Dans les ouvrages plus tardifs, qui privilégient les sources livresques, les procédés de comparaison et de choix des sources citées sont clairement exposés au lecteur. La citation livresque devient ainsi le moyen, pour un auteur, de revendiquer son individualité et l'originalité de son écriture.

Sources

\section{BIBLIOGRAPHIE}

Al- ${ }^{\mathrm{A}} \overline{\mathrm{A}} \mathrm{mil} \overline{1}$, al-Kašk $\bar{u} l, 2$ vols. (Beyrouth : Dār al-kutub al- ${ }^{\mathrm{c}}$ ilmiyya, 1998).

Dāwūd al-Anțākī, Tazyīn al-aswāq (Beyrouth : Dār wa-maktabat al-hilāl, 1994).

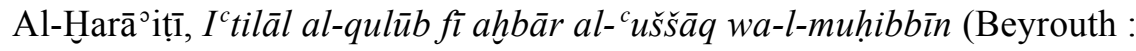
Dār al-kutub al-'ilmiyya, 2001).

Al-Ḥuṣrī, al-Mașūn fì sirr al-hawā al-maknūn (Le Caire : Maṭba ${ }^{\mathrm{c}}$ at alamāna, s.d).

Ibn Abī Ḥağala, Dīwān al-șabāba (Beyrout : Dār wa-maktabat al-Hilāl, 1999).

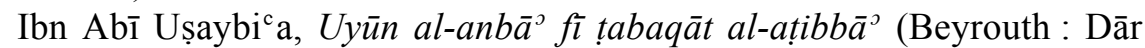
maktabat al-Ḥayyāt, 1965).

116 J. Berkey, The Transmission of Knowledge, 26. 


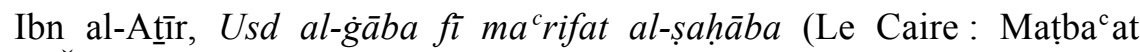
Ğama ${ }^{c}$ iyyat al-macārif, 1868-69).

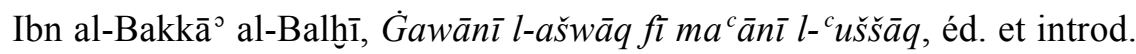
par George J. Kanazi (Wiesbaden : Harrassowitz Verlag, 2008).

Ibn Dāwūd al-Ișfahān̄̄, Kitāb al-Zahra, éd. A. R. Nykl (Chicago: University of Chicago Press, 1932).

Ibn Ḥazm, Tawq al-ḥamāma, éd. Iḥsan ${ }^{\mathrm{C}} \mathrm{Abbās}$ (Tunis : Dār al-ma ārif li1-țibāca wa-1-našr, 1992).

Ibn al-Ğawzī, Damm al-hawā (Beyrouth: Dār al-kutub al-cilmiyya, 1999).

Ibn Qayyim al-Ğawziyya, Rawḍat al-muhibbīn wa-nuzhat al-muštāqūn (Alep : Dār al-wa' ${ }^{c} y$, s.d.).

Ibn al-Ṭiqtaqā, al-Fahrī fì l-ādāb al-sultāniyya wa-l-duwal al-islamiyya (Le Caire : al-Maktaba al-tiğāriyya al-kubrā, 1927).

Kitāb As ${ }^{c} \bar{a} r$ al-aswāq fí aš $\bar{a} r$ al-ašwa àq, MS Tunis, Bibliothèque Nationale de Tunis, $176 \mathrm{mim}$.

Mugultạy, al-Wādịh al-mubīn fí dikr man ustušhida min al-muhibbīn (Beyrouth : $\mathrm{Mu}^{ }$assasat al-intišār al- ${ }^{\mathrm{c}}$ arabī, 1997).

_- al-Wādịh al-mubīn fi dikr man ustušhida min al-muhibbīn, Ms Istanbul (Süleymaniye), Fātih, 4143.

Al-Nuwayrī, Nihāyat al-arab fì funūn al-adab, 33 vols. (Beyrouth : Dār al-kutub al- ${ }^{c}$ ilmiyya, 2004).

Al-Șafadī, al-Wāfì bi-l-wāfayāt, 30 vols. (Wiesbaden: Franz Steiner Verlag, 1979).

Al-Sarrāğ, Mașāric $a l^{c}$ uššāq, 2 vols. (Beyrouth : Dār Bayrūt-Dār alnafā̄is, 1997).

Al-Šayzarī, Raw ḍat al-qulūb wa-nuzhat al-muhibb wa-l-mahbūb, éd. D. Semah et G. J. Kanazi (Wiesbaden : Harrawitz Verlag, 2003).

Šihāb al-Dīn Maḥmūd, Manāzil al-aḥbāb wa-manāzih al-albāb (Le Caire : Maktabat al-taysīr, 1989).

Yāqūt al-Ḥamawī, $M u^{c} \breve{g} a m$ al-udab $\bar{a}^{p}, 5$ vols. (Beyrouth : Dār al-kutub al- ${ }^{c}$ ilmiyya, 1991).

Études

Arié, Rachel, Études sur la civilisation de l'Espagne musulmane (Leiden : Brill, 1990).

Balda, Monica, 'Genèse et essor d'un genre littéraire : les traités d'amour dans la littérature arabo-islamique médiévale $\left(\mathrm{II}^{\mathrm{e}} / \mathrm{VIII}^{\mathrm{e}}-\mathrm{VIII}^{\mathrm{e}} / \mathrm{XIV}^{\mathrm{e}}\right.$ siècle)', Synergies Monde Arabe, 6 (2009), 121-30. 
Balda-Tillier, Monica, Un traité d'amour tardif : Le Précis des martyrs de l'amour de Mugultāy, thèse pour le doctorat de linguistique, littérature et civilisation arabes (Université Lyon 2, Septembre 2009).

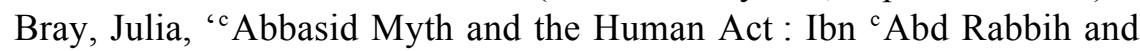
Others', dans P. F. Kennedy (éd.), On Fiction and Adab in Medieval Arabic Literature (Wiesbaden : Harrassowitz Verlag, 2005), 1-54.

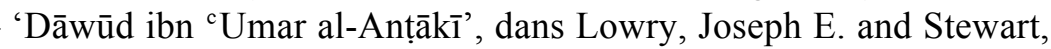
Devin J. (éds.), Essays in Arabic Literary Biography 1350-1850 (Wiesbaden : Harrowitz Verlag, 2009), 48-56.

Bell, Joseph N., Love Theory in Later Hanbalite Islam (Albany: State University of New York Press, 1979).

Ben Slama, Rağa $\bar{a}^{0}$ al- ${ }^{c} I \check{q} q$ wa-l-kitāba (Cologne: al-Kamel Verlag, 2003).

Berkey, Jonathan, The Transmission of Knowledge in Medieval Cairo. A Social History of Islamic Education (Princeton : Princeton University Press, 1992).

Blachère, Régis, 'Problème de la transfiguration du poète tribal en héros de roman 'courtois' chez les 'logographes' arabes du III $/ \mathrm{IX}^{\mathrm{e}}$ siècle', Arabica, 8 (1961), 131-6.

Brown, Jonathan A. C., Hadith. Muhammad's Legacy in the Medieval and Modern World (Oxford : One Word, 2009).

Cheikh-Moussa, Abdallah, 'La négation d'éros ou le 'išq d'après deux épîtres d'al-Ğāhịiz', Studia Islamica, 72 (1990), 71-119.

Gibb, H.A.R. et al., Encyclopédie de l'Islam, $2^{\mathrm{e}}$ éd., 13 vols. (LeidenParis : Brill-Maisonneuve Larose, 1960-2009).

Giffen, Lois A., Theory of Profane Love Among the Arabs, the Development of the Genre (New York: New York University Press, 1971).

Gruendler, Beatrice, 'Pardon Those Who Love Passionately', dans Friederike Pannewick (éd.), Martyrdom in Literature, Visions of Death and Meaningful Suffering in Europe and Middle East from Antiquity to Modernity (Wiesbaden : Reichert Verlag, 2004), 200-36.

—, 'Ibn Abī Hağala', dans Lowry, Joseph E. et Stewart, Devin J. (éds.), Essays in Arabic Literary Biography 1350-1850 (Wiesbaden: Harrowitz Verlag, 2009), 118-26.

Holtzman, Livnat, 'Ibn Qayyim al-Jawziyyah', dans Lowry, Joseph E. et Stewart, Devin J. (éds.), Essays in Arabic Literary Biography 13501850 (Wiesbaden : Harrowitz Verlag, 2009), 202-23.

Kilpatrick, Hilary, Making the Great Book of Songs. Compilation and Author's Craft in Abū l-Faraj al-Ișbahānī's Kitāb al-Aghānī (London : RoutledgeCurzon, 2003). 
Leder, Stefan, 'Spoken Word and Written Word Text: Meaning and Social Significance of the Institution of Riwāya', Islamic Area Studies Working Paper Series (University of Tokyo), 31 (March 2002), 1-16.

_, Ibn al-Ğauzī und seine Kompilation wider die Leidenschaft (Weisbaden-Beirut : Franz Steiner Verlag, 1984).

, 'The Literary Use of the Khabar: a Basic Form of Historical Writing', dans A. Cameron et L. I. Conrad (éds.), The Byzantine and Early Islamic Near East I, Problems in the Literary Source Material (Princeton : The Darwin Press, 1992), 277-315.

Lowry, Joseph E. and Stewart, Devin J. (éds.), Essays in Arabic Literary Biography 1350-1850 (Wiesbaden : Harrowitz Verlag, 2009).

Martinez, Gabriel, 'L'amour-trace! Réflexions sur le Collier de la colombe', Arabica, 34 (1987), 1-47.

Schoeler, Gregor, The Oral and the Written in Early Islam, trans. Uwe Vagelpohl (New York-London : Routledge, 2006).

Semah, David, 'Raw dat al-qulūb by al-Shayzarī, a Twelfth-Century Book on Love', Arabica, 24 (1977), 187-206.

Sublet, Jaqueline, 'Le modèle arabe, éléments de vocabulaire', dans N. Grandin et M. Gaborieau (éds.), Madrasa : La transmission du savoir dans le monde musulman (Paris : Éditions Arguments, 1997), 13-27.

Vadet, Jean-Claude, L'esprit courtois en orient dans les cinq premiers siècles de l'Hégire (Paris : Maisonneuve \& Larose, 1968).

Van Gelder, Geert J., [Review of] 'Ghawān̄i l-ashwāq fī ma ān̄̄ l${ }^{c}$ ushshāq/A Treatise on the Concept of Love in Classical and Medieval Arabic Heritage by ${ }^{\mathrm{c}} \mathrm{Abd}$ al-Mucīn ibn Aḥmad Ibn al-Bakkāa ${ }^{\mathrm{c}}$ alBalkhī', Journal of Islamic Studies, 22 (2011), 72-4. 